\title{
Mercury in organisms from the Northwestern Mediterranean slope: Importance of food sources
}

\author{
P. Cresson ${ }^{a,}{ }^{,}$, M.C. Fabri ${ }^{a,}$, M. Bouchoucha ${ }^{a}$, C. Brach Papa ${ }^{b}$, F. Chavanon ${ }^{a}$, A. Jadaud ${ }^{c}$, J. Knoery ${ }^{b}$, \\ F. Miralles ${ }^{a}, D$. Cossa ${ }^{a, d}$
}

\author{
a Ifremer, Centre de Méditerranée, CS 20330, F-83 507 La Seyne-sur-Mer, France \\ ${ }^{b}$ Ifremer, Centre Atlantique, BP 21105, F-44311 Nantes Cedex 03, France \\ c Ifremer, Centre de Méditerranée, CS 30171, F-34203 Sète Cedex, France \\ d IS Terre, Université Joseph Fourier, BP 53, F-38041 Grenoble, France
}

\author{
*: Corresponding author : P. Cresson, tel.: + 33494304874 ; fax: + 33494304417 ; email address : \\ pierre.cresson@ifremer.fr
}

marie.claire.fabri@ifremer.fr ; marc.bouchoucha@ifremer.fr ; christophe.brach.papa@ifremer.fr ; fabienne.chavanon@ifremer.fr ; angelique.jadaud@ifremer.fr ; joel.knoery@ifremer.fr ; fmarco@ifremer.fr ; daniel.cossa@ifremer.fr

\begin{abstract}
:
Mercury $(\mathrm{Hg})$ is a global threat for marine ecosystems, especially within the Mediterranean Sea. The concern is higher for deep-sea organisms, as the $\mathrm{Hg}$ concentration in their tissues is commonly high. To assess the influence of food supply at two trophic levels, total $\mathrm{Hg}$ concentrations and carbon and nitrogen stable isotope ratios were determined in 7 species (4 teleosts, 2 sharks, and 1 crustacean) sampled on the upper part of the continental slope of the Gulf of Lions (Northwestern Mediterranean Sea), at depths between 284 and $816 \mathrm{~m}$. Mean $\mathrm{Hg}$ concentrations ranged from $1.30 \pm 0.61$ to $7.13 \pm 7.09 \mathrm{\mu g} \mathrm{g}^{-1}$ dry mass, with maximum values observed for small-spotted catshark Scyliorhinus canicula. For all species except blue whiting Micromesistius poutassou, $\mathrm{Hg}$ concentrations were above the health safety limits for human consumption defined by the European Commission, with a variable proportion of the individuals exceeding limits (from $23 \%$ for the Norway lobster Nephrops norvegicus to $82 \%$ for the blackbelly rosefish Helicolenus dactylopterus). Measured concentrations increased with increasing trophic levels. Carbon isotopic ratios measured for these organisms demonstrated that settling phytoplanktonic organic matter is not only the main source fueling trophic webs but also the carrier of $\mathrm{Hg}$ to this habitat. Inter- and intraspecific variations of $\mathrm{Hg}$ concentrations revealed the importance of feeding patterns in $\mathrm{Hg}$ bioaccumulation. In addition, biological parameters, such as growth rate or bathymetric range explain the observed contamination trends.
\end{abstract}

\section{Highlights}

$\mathrm{Hg}$ and stable isotope ratios were assessed in 7 species from Mediterranean slope. Settling phytoplankton was the main $\mathrm{OM}$ and $\mathrm{Hg}$ source, as confirmed by $\delta^{13} \mathrm{C}$ values. All species except one exceeded $\mathrm{Hg}$ consumption limits. Depth and diet were important factors explaining Hg content.

- Results confirmed the concern about $\mathrm{Hg}$ in the deep Mediterranean.

Keywords: Continental slope ; Trophic webs ; Depth ; Teleosts ; Sharks ; Stable isotopes 


\section{Introduction}

Anthropogenic inputs of chemicals is one of the main threats currently affecting the global ocean (Halpern et al., 2008). Amongst other contaminants, mercury $(\mathrm{Hg})$ is assessed as being of great concern (UNEP, 2013), since it is a neurotoxic metal for mammals. It also affects fish and other animals at levels below acute toxicity (Fitzgerald and Clarkson, 1991; Scheuhammer et al., 2007; Tartu et al., 2013). The volatile metallic form of $\mathrm{Hg}\left(\mathrm{Hg}^{0}\right)$ is emitted in the environment from both natural and anthropogenic sources, with an increase of anthropic releases in the last centuries (Streets et al., 2011; UNEP, 2013). Its 1 year atmospheric residence time allows $\mathrm{Hg}$ to be transported over long distances (Streets et al., 2011; UNEP, 2013). However, $\mathrm{Hg}^{0}$ is partly photooxidized into its divalent form $\left(\mathrm{Hg}^{\prime \prime}\right)$ in the atmosphere and dissolved in rain or dry deposited. Once deposited, $\mathrm{Hg}^{\prime \prime}$ can be methylated by bacteria in soil, marine waters, and sediments (Fitzgerald \& Lamborg 2006). Methylation mainly occurs in low oxygen zones, and at the water/sediment interface, where heterotrophic bacterial activity is at a maximum (Blum et al., 2013; Cossa, 2013; Cossa et al., 2009; 2013; Heimbürger et al., 2010). Methylmercury (MeHg) is the chemical form of mercury of greatest concern, since it can easily be uptaken by phytoplankton and magnified along trophic webs (Pickhardt and Fisher, 2007). Bioaccumulation (bioconcentration + biomagnification) is determined by complex processes, linked with metabolic specificities of each organism and physico-chemical properties of the contaminant (e.g. Harmelin-Vivien et al., 2012). Bioconcentration factors of $10^{4}$ to $10^{7}$ were observed for $\mathrm{Hg}$ concentrations between marine waters and organisms (Cossa et al., 2012). This process is responsible for the highest $\mathrm{Hg}$ concentrations observed in high trophic level species, and for risks for humans when consuming high trophic level marine organisms, like piscivorous fishes (Morel et al., 1998).

The fate of $\mathrm{Hg}$ is particularly important for the Mediterranean Sea. The anthropogenic pressure is thus high, as most of the countries around the Mediterranean are highly populated and industrialized (Durrieu de Madron et al., 2011). Since the 1970's, several authors have described high $\mathrm{Hg}$ concentrations in Mediterranean teleosts (ray-finned fishes), sharks, and marine mammals. In addition, higher concentrations were observed for Mediterranean organisms when compared with the same species in others oceans, despite rather similar concentrations in waters (Andre et al., 1991; Cossa et al., 2012; Harmelin-Vivien et al., 2009; Thibaud, 1971). On the basis of these observations, several early papers called this trend the "Mediterranean mercury anomaly" and research was undertaken to look for the cause (Aston and Fowler, 1985; Cossa and Coquery, 2005). One hypothesis is that it may be linked to the biogeochemistry of $\mathrm{Hg}$ and the methylation depth range. In the Mediterranean, the oxygen minimum zone is shallower than in other marine environments. The methylation zone occurs thus at a lower depth, increasing the potential for $\mathrm{MeHg}$ to be integrated in the trophic webs, which are shallow (Cossa et al., 2009; 2012). The second hypothesis focuses on a lower primary productivity in the oligotrophic Mediterranean, and thus a lower "biodilution" of contamination into less abundant biogenic particles at the base of trophic webs (Heimbürger et al., 2010). This lower productivity also reduces the growth rate of higher organisms compared to more eutrophic settings. This has been observed for hake (Merluccius merluccius), a predatory teleost (Mellon-Duval et al., 2010). At the same size, a Mediterranean individual is older and shows higher $\mathrm{Hg}$ levels than its Atlantic counterpart, due to a slower growth rate, and increased exposure time -hence, a higher potential for bioaccumulation (Cossa et al., 2012).

Assessment of mercury concentrations was mainly performed in shallow Mediterranean species of commercial or cultural interest. Numerous studies have investigated trophic position and $\mathrm{Hg}$ concentration in species such as hake, mullet, tuna or marine mammals (Andre et al., 1991; Cossa et al., 2012; Harmelin-Vivien et al., 2009; Storelli and Barone, 2013; Storelli et al., 2005; Thibaud, 
1971). Fewer data are available regarding $\mathrm{Hg}$ concentrations for species living in deep Mediterranean waters (e.g. Cossa and Coquery, 2005; Hornhung et al., 1993; Koenig et al., 2013). However, there is considerable concern regarding $\mathrm{Hg}$ for these species. They are commonly considered as long-lived and slow-growing, which increases potential exposure time to contamination (Drazen and Haedrich, 2012; Koenig et al., 2013), given that deep-sea sediment with high concentrations of $\mathrm{Hg}$ have been observed in the Mediterranean Sea (Heimbürger et al., 2012).

Recently, Canals et al. (2013) reported that a strong research effort had been undertaken to assess the hydrological and climatic processes of the deep areas (mainly continental slopes and submarines canyons) of the Gulf of Lions (Northwestern Mediterranean Sea), but little has been done to connect physical trends to biological functioning. They stated that there is an urgent need to "identify major issues and threats affecting deep-sea ecosystems, and to evaluate their potential impacts". Among the missing knowledge that is required for this assessment are the origin of organic matter (OM) and the functioning of trophic webs in these zones. As diet is the main source of contamination for fishes (Hall et al., 1997), understanding what food source fuels deep-sea organisms is crucial to better understand their contamination patterns. Some early papers performed extensive studies of the diet of some teleosts and shark species (eg Carrassón et al., 1992; Macpherson, 1979; 1981; Morte et al., 2002) whereas more recent research characterized the OM reaching deep zones (Canals et al., 2006; Heussner et al., 2006; Pasqual et al., 2013; Sanchez-Vidal et al., 2013).

Although stable isotopes have been used to understand food webs in deep Mediterranean zones (Fanelli et al., 2011; 2013; Papiol et al., 2013, Polunin et al., 2001), the connection between OM and $\mathrm{Hg}$ at the base and consumers at the top of the trophic web has not been investigated. Stable isotope analyses would be useful to determine the source of $\mathrm{OM}$ and also $\mathrm{Hg}$ in deep Mediterranean trophic webs. Two OM and Hg sources could been considered, Rhône river OM inputs and sedimentation of phytoplanktonic OM. Stable isotope analyses are based on the link between the isotopic ratio of a consumer and the ratio of its diet, with a known fractionation factor between them. For carbon, this factor is rather low (theoretically $+1 \%$ at each trophic level), and allows the use of carbon as a tracer of the origin of OM supporting the consumer. Fractionation factor is more important for nitrogen (theoretically $+3.4 \%$ at each trophic level). Nitrogen is thus commonly used as a proxy of trophic level. Nevertheless, recently published studies demonstrated that these fractionation factors can vary with feeding behavior, trophic position, metabolism, body size or temperature (Cresson et al., 2014; Hussey et al., 2014; Mill et al., 2007; Wyatt et al., 2010). Using stable isotopes is appropriate for understanding trophic levels in deep-sea species in addition with the gut content analyses, as this technique suffers drawbacks (Drazen et al., 2008; Fanelli et al., 2011; Polunin et al., 2001). Due to rapid pressure change, deep-sea species commonly regurgitate their stomach content when caught. Feeding is also sporadic for carnivorous species. Extensive sampling is thus needed to avoid empty or regurgitated stomachs and to get reliable data. Finally, combining stable isotope and contaminant analyses is a powerful approach, as both techniques give integrated information on diet or contamination processes.

There is a paucity of data about the $\mathrm{Hg}$ concentration and trophic relationships of teleosts and sharks of the Mediterranean continental slope (Canals et al., 2013). Furthermore, the existing data have been collected in the Western part of the Gulf of Lions. It is generally considered that deep sea species exhibit high $\mathrm{Hg}$ concentration, suggesting that biological features of deep-dwelling species, trophic position, and nature of OM fueling deep zones can drive the high contamination pattern. Consequently, the aim of this study was (1) to characterize the trophic position of seven potentially high-trophic level species of sharks (Blackmouth catshark Galeus melastomus, Smallspotted catshark Scyliorhinus canicula) teleosts (Blackbelly rosefish Helicolenus dactylopterus, Four-spot megrim Lepidorhombus boscii, Blue whiting Micromesistius poutassou, and Greater 
forkbeard Phycis blennoides) and crustacean (Norway lobster Nephrops norvegicus) in the upper continental slope of the French part of the Gulf of Lions (2) to gain knowledge on species $\mathrm{Hg}$ concentrations, and (3) to explain the Hg concentrations in the trophic web using stable isotopes.

\section{Material and methods}

\subsection{Study area, organism sampling and dissection}

Sampling was performed during the 2012 MEDITS bottom trawl campaign in the Gulf of Lions (R/V L'Europe) at 6 stations, located on the upper slope at depths between 284 and $816 \mathrm{~m}$ (Fig. 1). The MEDITS annual bottom trawl surveys have applied a common standardized protocol since 1994 to produce information on benthic and demersal species on the continental shelves and along the upper slopes in the whole Mediterranean Sea (Bertrand et al., 2002). Sites were selected with regard to the targeted species usually collected there. A total of seven species was chosen, due to their repeated observation during video recorded in the canyons heads (Fabri et al., 2014), the high trophic level of teleosts and sharks (Carrassón et al., 1992; Macpherson, 1978; 1979; 1981; Morte et al., 2002; Papiol et al., 2013; Stergiou and Karpouzi, 2002; Tecchio et al., 2013) their importance for the community composition and functioning (Papiol et al. 2013; Tecchio et al., 2013) and their ability to feed on prey coming from the submarine canyons. As their have high trophic level, these species were supposed to exhibit high $\mathrm{Hg}$ concentration. On the contrary, Norway lobster has a lower trophic level, as it mainly consume small benthic invertebrates (Cristo and Cartes, 1998). In addition, these species can have some commercial interest and can be caught by professional fishermen (Fisheries Information System Ifremer, Patrick Lespagnol, pers. comm.). Individual organisms were stored frozen on board and kept at $-20^{\circ} \mathrm{C}$ until dissection.

In the lab, teleosts and sharks were thawed, measured (total length, to the nearest $\mathrm{mm}$ ) and weighed (total, mass, to the nearest $0.1 \mathrm{~g}$ ) before dissection. For the decapod crustacean species Nephrops norvegicus, the cephalothorax length was measured to the nearest millimeter. For all species, two samples of muscle were taken from thawed individuals and prepared for analyses. White dorsal muscle was taken for stable isotope analyses, as this tissue was demonstrated to be the most appropriate (Pinnegar and Polunin, 1999). For Hg analysis, a sample of muscle was taken from the caudal peduncle, between the anal pore and the tail. Muscle taken in this zone was observed to be the most suitable for $\mathrm{Hg}$ analysis, according to international guidelines (Nakhlé et al., 2007). All muscle samples were stored frozen, freeze-dried and ground in a non-contaminating blender before analyses.

\subsection{Carbon and nitrogen stable isotope and $\mathrm{Hg}$ concentration determination}

Stable isotope ratio measurement was performed with a continuous flow mass spectrometer (Delta $\checkmark$ Advantage, Thermo Scientific, Bremen, Germany) coupled with an elemental analyzer (Flash EA 1112 Thermo Scientific, Milan, Italy). Results are expressed following the standard $\delta$ notation,

where $\delta X=\left(\frac{R_{\text {sample }}}{R_{\text {standard }}}-1\right) \times 10^{3}$, (equation 1)

with $\mathrm{X}$ is ${ }^{13} \mathrm{C}$ or ${ }^{15} \mathrm{~N}$ and $\mathrm{R}$ the ratio ${ }^{13} \mathrm{C} /{ }^{12} \mathrm{C}$ and ${ }^{15} \mathrm{~N} /{ }^{14} \mathrm{~N}$ respectively. Standards used were Vienna PeeDee Belemnite for $\mathrm{C}$ and $\mathrm{N}_{2}$ for $\mathrm{N}$. Measurement precision was $<0.1 \%$ for $\mathrm{C}$ and $\mathrm{N}$, and was checked by repeated measurement of an internal laboratory standard of acetanilide. One determination of $\delta^{13} \mathrm{C}$ and $\delta^{15} \mathrm{~N}$ was performed for each individual, as previous results demonstrated low variability of repeated analyses of the same sample (Cresson et al. 2014). C/N 
ratios were determined with the elemental analyzer, and were used as a proxy of lipid content. High lipid concentrations were previously observed in deep-sea teleosts, and could represent a bias for the measurement of $\delta^{13} \mathrm{C}$. $\mathrm{C} / \mathrm{N}$ values lower than 4 indicates no lipid bias and no need for correction (Hoffman and Sutton, 2010). In our dataset, all $\mathrm{C} / \mathrm{N}$ values were below this threshold. Consequently, no lipid bias correction was performed.

Total $\mathrm{Hg}$ concentration was determined using a semi-automated atomic absorption spectrophotometer (AMA-254, Altec Ltd., Praha, Czech Republic) in three steps: (1) combustion of the sample and volatilization of $\mathrm{Hg}$, (2) amalgamation of elemental $\mathrm{Hg}$ on a gold trap, and (3) spectrophotometric atomic absorption measurement of the $\mathrm{Hg}$ swept into the flow cell following heating $\left(800^{\circ} \mathrm{C}\right)$ of the gold trap. Precision of the technique was assessed using certified reference materials from the National Research Council of Canada (DORM-2 and -4), chosen in accordance with the $\mathrm{Hg}$ concentration of the sample. Measured values were always within the confidence limits of the certified materials (certified values: $4.64 \pm 0.26$ and $0.410 \pm 0.055 \mu \mathrm{g} \mathrm{g}^{-1}$; measured values: $4.73 \pm 0.27$ and $0.392 \pm 0.007 \mu g^{-1}$ for DORM-2 and DORM-4 respectively). Reproducibility of the measurements were usually better than $5 \%$. This technique allows determination of the total $\mathrm{Hg}$ but not the methylmercury $(\mathrm{MeHg})$. However, previous results demonstrated that total $\mathrm{Hg}$ is a good proxy of $\mathrm{MeHg}$, as $\mathrm{MeHg}$ represent 80 to $100 \%$ of $\mathrm{Hg}$ in teleosts and sharks (Bloom, 1992; Magalhães et al., 2007; Pethybridge et al., 2010). Concentrations are expressed relatively to the dry mass of individuals. If needed, wet masses (wm) were converted into dry masses (dm), considering that $\mathrm{dm}=5 \mathrm{wm}$ (Magalhães et al., 2007). One determination of $\mathrm{Hg}$ concentration was performed for each individual, as previous results demonstrated low variability of $\mathrm{Hg}$ concentrations for repeated analyses of the same sample (F. Miralles, unpubl. data)

To determine what OM source potentially fuels slope trophic webs, no specific sampling was performed, but bibliographical data were gathered. The Rhône river $\mathrm{OM}$ inputs exhibit $\delta^{13} \mathrm{C}$ values lower than $-25 \%$, consistent with other reported terrestrial OM inputs in the Gulf of Lions (e.g. Cresson et al., 2012; Darnaude et al., 2004; Harmelin-Vivien et al., 2010; Sanchez-Vidal et al., 2013; Tesi et al., 2007). These values are explained by the predominance of $C_{3}$ plants remains in riverine OM. Regarding phytoplankton, most of the studies so far in the Mediterranean considered isotopic ratio of POM, i.e. the heterogeneous mixture of living and detrital particles (e.g. Cresson et al., 2012; Darnaude et al., 2004; Tesi et al., 2007). POM isotopic ratios can be considered as a proxy of phytoplankton isotopic ratios only under particular conditions, like the absence of terrigeneous influences. To our knowledge, isotopic ratios of "pure" phytoplankton from the Gulf of Lions was only reported once (Harmelin-Vivien et al., 2008). Briefly, these authors specifically sampled phytoplankton by pumping large volume of water at the fluorescence maximum depth, filtering, and considering only the $63-200 \mu \mathrm{m}$ fraction. This size class was considered the best proxy of phytoplankton as it was composed mainly of diatoms and dinobionts, as confirmed by species identification. They measure $\delta^{13} \mathrm{C}$ values between $-21 \%$ and $-19 \%$ for phytoplankton. Their results were previously used to confirm the contribution of phytoplanktonic OM to deep Mediterranean environments (Fanelli et al., 2013; Sanchez-Vidal et al., 2008). Marked differences between riverine and phytoplanktonic $\delta^{13} \mathrm{C}$ allowed the use of these values to discriminate what OM source fuels slope trophic webs.

\subsection{Statistical analyses}

Interspecific variations of $\delta^{13} \mathrm{C}, \delta^{15} \mathrm{~N}$ and spatial variation of total length were tested. In both cases, normality and homogeneity of variance were first checked. If those assumptions were reached, comparisons were performed with one-way ANOVAs. If not, non-parametric tests (Mann-Whitney or Kruskall Wallis) were used. 
As length can affect isotopic ratio or $\mathrm{Hg}$ concentration, correlations between parameters were assessed using linear or exponential regression models, using Generalized Linear Models (GLM). After checking the significance of the regression ( $p$-value $\leq 0.05$ ), the model minimizing the Aikake Information Criterion (AIC) was considered the best fit. When linear correlation was the best fit, spatial variations were tested on untransformed data with ANCOVA, using length as a covariate. When exponential regression best fit the data, ANCOVA was performed on log-transformed data. Spatial variation was not tested for Nephrops norvegicus (sampled in one site only $n=13$ ). Data discussed as significant is for $p<0.05$.

\section{Results}

\subsection{Isotopic and biometrical features.}

A total of 153 individuals were included in this work (Tab. 1). Mean $\delta^{13} \mathrm{C}$ values displayed a range lower than $1 \%$ (Tab.1, Fig.2) between the maximum value measured for Scyliorhinus canicula ($18.32 \pm 0.45 \%$ ) and the minimum for Micromesistius poutassou $(-19.11 \pm 0.59 \%$ ). Values measured on each sampling point are detailed in Table S1.One large $(611 \mathrm{~mm})$ L. piscatorius individual was also collected and displayed high isotopic ratios $\left(\delta^{13} \mathrm{C}=-17.39 \%\right.$, $\delta^{15} \mathrm{~N}=9.91 \%$ ) and $\mathrm{Hg}$ burden $\left(6.55 \mu \mathrm{g} \mathrm{g}^{-1} \mathrm{dm}\right)$. This individual was not included in the statistical analyses, as its representativeness in the data set was low.

Nitrogen isotopic ratios were rather similar between teleosts and sharks, as a difference of nearly $1 \%$ is observed between $\delta^{15} \mathrm{~N}$ values measured for Lepidorhombus boscii $(7.89 \pm 0.53 \%$ ) and Phycis blennoides $\left(9.06 \pm 0.70 \%\right.$ ). $N$. norvegicus $\delta^{15} \mathrm{~N}$ value $(6.62 \pm 0.55 \%$ ) was significantly lower than values measured for teleosts and sharks (Fig. 2).

Assuming a $\sim 1 \%$ enrichment factor for carbon per trophic level, and considering that phytoplankton $\delta^{13} \mathrm{C}$ values range between -21 and $-19 \%$, isotopic ratios measured for all teleosts, sharks, and decapod crustaceans in this work were consistent with the predominance of phytoplankton as the main OM source fueling the slope trophic webs. This idea is supported by the position of all species in the $\delta^{13} \mathrm{C}-\delta^{15} \mathrm{~N}$ biplot (Fig. 2). All species are in the blue (light gray) area representing the limits of the range of isotopic ratios expected if the trophic web they belong to is mainly fueled by phytoplanktonic OM. On the contrary, all available data about riverine inputs' $\delta^{13} \mathrm{C}$ were markedly lower and suggests that this food source is not available to the slope trophic webs.

For all species, significant correlations were observed between length and isotopic ratios (Tab S3 and S4). Mean lengths were similar between sites, revealing rather homogeneous sampling (Fig. 3). Nevertheless, some spatial variation of isotopic ratios were observed when length was used as a covariate (Tab. 2). Generally, differences seemed to appear between shallower and deeper individuals. As an example, $\mathrm{H}$. dactylopterus captured at $679 \mathrm{~m}$ depth exhibited the higher average $\delta^{15} \mathrm{~N}$ and $\delta^{13} \mathrm{C}$ values $(9.74 \pm 0.36 \%$ and $-17.81 \pm 0.30 \%$ respectively), whereas lowest values were recorded for individuals captured shallower.

\subsection{Hg concentrations}

$\mathrm{Hg}$ displayed a wide range of values, with major and significant $\left(\mathrm{KW} \mathrm{H}_{(6,153)}=68.55, \mathrm{p}<0.0001\right)$ differences between species (Tab.1, Fig. 4). Three species exhibited low and similar values: Micromesistius poutassou (1.30 $\pm 0.61 \mathrm{mg} \mathrm{g}^{-1}$ dry mass), $N$. norvegicus $\left(1.80 \pm 0.97 \mu \mathrm{g} \mathrm{g}^{-1} \mathrm{dm}\right)$ and $P$. blennoides $\left(1.89 \pm 1.10 \mu \mathrm{g} \mathrm{g}^{-1} \mathrm{dm}\right)$. M. poutassou was the only species with all individual displaying concentrations below the European maximal levels in foodstuffs of $2.5 \mu \mathrm{g} \mathrm{g}^{-1} \mathrm{dm}_{\text {for }}$ this 
species (EC, 2006). Maximum average values were recorded for Scyliorhinus canicula (7.13 \pm 7.09 $\left.\mu \mathrm{g} \mathrm{g}{ }^{-1} \mathrm{dm}\right)$, Helicolenus dactylopterus $\left(5.80 \pm 3.24 \mu \mathrm{g} \mathrm{g}^{-1} \mathrm{dm}\right)$ and Galeus melastomus (4.92 \pm 3.66 $\mu \mathrm{g} \mathrm{g}^{-1} \mathrm{dm}$ ). Maximum concentrations were recorded in muscle of three large $S$. canicula individuals (27.01, 18.08 and $17.11 \mathrm{\mu g} \mathrm{g}^{-1} \mathrm{dm}$ respectively). Intraspecific variation was also high and explained the large standard deviation calculated (Fig. 4). Significant correlations were observed between length or $\delta^{15} \mathrm{~N}$ and total $\mathrm{Hg}$ concentration, whatever the species (Fig. 5, Tab. S3). In most cases, the exponential model best fitted the data (Fig. 5). Largest individuals exhibited high $\delta^{15} \mathrm{~N}$ and high $\mathrm{Hg}$ concentrations, most of them above the limits $\left(2.5\right.$ or $5 \mu \mathrm{g} \mathrm{g}^{-1} \mathrm{dm}$ ) defined by European Commission (EC, 2006). Furthermore, with the exception of $M$. poutassou, several individuals from all species exhibited $\mathrm{Hg}$ concentrations above the human consumption safety limit, with different proportions of individuals above the limits for each species (Fig. 4). Spatial differences of $\mathrm{Hg}$ concentrations were only observed for $H$. dactylopterus and $P$. blennoides, with individuals collected deeper displaying higher concentrations (Tab. 2). Hg concentration is higher (9.61 \pm 2.69 $\mu \mathrm{g} \mathrm{g}^{-1} \mathrm{dm}$ ) for $H$ dactylopterus captured at $679 \mathrm{~m}$ than at all other shallower sites. Similar trend is observed for $P$. blennoides, as individuals sampled at 665, 679 and $816 \mathrm{~m}$ depth were Hg-enriched compared with individuals sampled at 284 and $426 \mathrm{~m}$.

\section{Discussion}

Fish and shellfish assimilate $\mathrm{Hg}$, mainly from their food via the biomagnification process (e. g., Magalhães et al., 2007). Their diet (and thus trophic level) is the main factor governing the amplitude of $\mathrm{Hg}$ accumulation in marine organisms. In addition, $\mathrm{Hg}$ concentrations tend to increase with animal age that depends on their growth rate, which in turn, change in function of the habitat, physiology, and reproductive cycle (Cossa et al., 2012).

\subsection{Marine vs terrestrial OM fueling trophic webs}

Organisms analyzed here displayed isotopic ratios consistent with trophic webs supported by phytoplanktonic OM (Fig. 2). The importance of sinking phytoplankton, as the main source fueling deep trophic webs was previously determined at other Mediterranean sites (Fanelli et al., 2013; Polunin et al., 2001) and in abyssal zones in the Pacific (Drazen et al., 2008). Fanelli et al (2013) calculated that falling phytoplankton was the major (67 to $85 \%$ ) contributor to deep water and sediment OM. The Gulf of Lions is commonly considered as a mesotrophic environment, more productive than other zones of the northwestern Mediterranean (Bosc et al., 2004). Phytoplanktonic $\mathrm{OM}$ can be then exported to the continental slope ecosystem, as confirmed by the presence of biogenic remains (diatoms and coccoliths) in particle traps (Heussner et al., 2006) and by the isotopic ratios and biochemical composition of these particles (Lopez-Fernandez et al., 2013; Sanchez-Vidal et al., 2008). Heussner et al. (2006) estimated that, at the scale of the Gulf of Lions, inputs of phytoplankton to deep-sea ecosystem represent nearly $9 \times 10^{5} \mathrm{t} \mathrm{a}^{-1}$, with a decreasing amount and quality of OM with depth, by example due to the fast consumption of labile OM. Alteration of OM, with a potential effect of bacterial processes, can also alter its isotopic ratios, and was proposed as an explanation of the effect of depth on isotopic ratio previously observed (Fanelli et al., 2013; Polunin et al., 2001). This could similarly explain the few but occurring $\delta^{13} \mathrm{C}$ differences observed for $H$. dactylopterus and $P$. blennoides sampled at different depths.

The lack of influence of terrestrial inputs on the trophic web of the continental slope may seem unexpected. The Rhône River is the main input of OM in the Gulf of Lions. Several papers have previously documented a strong influence of this river as a source of OM and contaminants for coastal teleosts populations, even far from its mouth (Carlier et al., 2007; Darnaude et al., 2004; Dierking et al., 2009; Morat et al., 2014). Some others smaller rivers may also carry OM to the sea, 
for example during flash flooding events (Sanchez-Vidal et al., 2013). These inputs can then be exported beyond the shelf break during downwellings or cascading events that occur under specific atmospheric forcings (Canals et al., 2013; Sanchez-Vidal et al., 2008). Nevertheless, fluxes of riverine OM appeared too limited in time and space to have a strong influence on the trophic webs leading to the organisms considered in this work. They occur sporadically during short periods of time, when atmospheric forcing is favorable and concomitant with winter flooding. Additionally, large OM inputs of the Rhône River are commonly exported to the West of the Gulf of Lions by the Northern Mediterranean Current, and influence mainly the western part of the Gulf of Lions, far from the sampling zone. Consequently, it can be hypothesized that terrestrial OM is of minor importance as a source for trophic webs in the upper part of the continental slope.

\subsection{High Hg concentration in the slope's organisms}

Results obtained here confirm the previously raised $\mathrm{Hg}$ concern for Mediterranean organisms (Andre et al., 1991; Cossa and Coquery, 2005; Cossa et al., 2012; Harmelin-Vivien et al., 2009; 2012; Koenig et al., 2013; Storelli and Barone, 2013; Storelli et al., 2007). Individuals with Hg concentrations above the European Commission quality standards (EC, 2006) were observed for all species except $M$. poutassou. Mean values observed for teleosts and sharks considered in this work are even higher than values previously reported for these species (Table 3) and also for species at similar trophic level in the Mediterranean. Previous values reported for piscivorous species show mean $\mathrm{Hg}$ concentrations between 0.5 to $1 \mathrm{\mu g} \mathrm{g}^{-1} \mathrm{dm}$, and maximum values generally lower than $2.5 \mathrm{\mu g} \mathrm{g}^{-1} \mathrm{dm}$ (Cossa et al., 2012; Harmelin-Vivien et al., 2012; Koenig et al., 2013; Storelli and Barone, 2013; Storelli et al., 2005). Mean values observed in this work were at least similar or higher than these maximum values. For example, Storelli et al. (2005) reported a maximum value of $2.02 \mathrm{\mu g} \mathrm{g}^{-1} \mathrm{dm}$ for $S$. canicula, which is well below the average $\left(7.13 \pm 7.09 \mu \mathrm{g} \mathrm{g}^{-}\right.$ $\left.{ }^{1} \mathrm{dm}\right)$ and maximum $\left(27.01 \mu \mathrm{g} \mathrm{g}^{-1} \mathrm{dm}\right)$ values observed here.

Food supply is considered as the main source of Hg contamination in fishes (Hall et al., 1997), and the patterns observed in this work are consistent with this idea. First, all teleosts and shark species sampled in this work were at similar high trophic levels. Previous results on their diet demonstrated that they feed mainly on teleosts, cephalopods and crustaceans (Carrassón et al., 1992; Macpherson, 1978; 1979; 1981; Morte et al., 2002; Papiol et al., 2013; Stergiou and Karpouzi, 2002; Tecchio et al., 2013). Due to magnification processes, high concentrations of $\mathrm{Hg}$ are observed in high trophic level species. Conversely, $\delta^{15} \mathrm{~N}$ values were significantly lower for $N$. norvegicus. As the majority of the crustaceans, Norway lobsters displayed a diverse diet mainly based on benthic invertebrates, such as other crustaceans, polychaetes or echinoderms (Cristo and Cartes, 1998). Their $\delta^{15} \mathrm{~N}$ ratio, nearly $2 \%$ lower than the ratios measured for teleosts and sharks, is consistent with this diet. The lower $\mathrm{Hg}$ concentration in $\mathrm{N}$. norvegicus is thus consistent with its trophic position nearly one trophic level below teleosts and sharks.

The importance of food source as a key to explaining contamination patterns is also evidenced by the exponential increase of concentrations observed in almost all species coincidently with increasing $\delta^{15} \mathrm{~N}$ and length. While ageing and growing, individuals alter their diet, and feed on prey that are at a higher trophic level. For example juvenile sharks Galeus melastomus or Scyliorhinus canicula mainly consume crustaceans while adults eat fish and cephalopods (Carrassón et al., 1992; Fanelli et al., 2009; Macpherson, 1979). Thus, $\delta^{15} \mathrm{~N}$ and $\mathrm{Hg}$ concentration increase with length increase and consumption of more contaminated prey. Thus alteration of the diet could be an explanation for the rather low average $\mathrm{Hg}$ concentrations measured for the teleost species Phycis blennoides. Small individuals $(<150 \mathrm{~mm}$ ) are commonly thought to eat benthic crustaceans such as Alpheus glaber or Calocaris macandrae whereas individuals larger than $250 \mathrm{~mm}$ prey on teleosts (Macpherson, 1978). In our study, small individuals have low $\delta^{15} \mathrm{~N}$ values $(\sim 8 \%$ and $\mathrm{Hg}$ 
concentrations $\left(<0.5 \mu \mathrm{g} \mathrm{g}^{-1} \mathrm{dm}\right)$, whereas large individuals exhibited high $\delta^{15} \mathrm{~N}$ values $(>9.5 \%$ ) and $\mathrm{Hg}$ concentrations (between 3.5 and $4.2 \mu \mathrm{g} \mathrm{g}^{-1} \mathrm{dm}$ ) similar to values measured for other piscivores in our work. Furthermore, $\mathrm{Hg}$ concentration was best fitted most of the time by an exponential model, considering either the effect of trophic level or length. An exponential regression between $\mathrm{Hg}$ and length, weight or isotopic parameters was previously observed for numerous teleosts species (Harmelin-Vivien et al., 2009, 2012; Hornhung et al., 1993; Magalhães et al., 2007; Storelli et al., 2005). This exponential-shaped bioaccumulation was explained by a change in the metabolism with age, in addition to the switch in the diet previously explained. Young individuals are sexually immature, and have a high growth rate. Contamination is thus diluted with rapid synthesis of new tissues. Consequently, accumulation in the first stages of life follows a pseudolinear pattern also observed for short-lived species (Magalhães et al., 2007). When acquiring sexual maturity, the somatic growth of individuals is slowed down, as individuals invest part of their energy in gonad synthesis, and bioaccumulation increases exponentially (Cossa et al., 2012). As $\mathrm{Hg}$ has an affinity for proteins, little decontamination occurs via the release of gametes (in contrast to the decontamination during reproduction observed for lipophilic contaminants) and larger individuals exhibit high $\mathrm{Hg}$ concentrations. Thus, $\mathrm{Hg}$ concentration changes with age depending on food supply, ontogenetic evolution, and growth rate.

\subsection{Effect of depth on $\mathrm{Hg}$ concentration}

The high $\mathrm{Hg}$ concentrations measured for organisms sampled on the continental slope were consistent with the high Hg content in deep-sea organisms (Blum et al., 2013; Chouvelon et al., 2012; Choy et al., 2009; Hornhung et al., 1993; Koenig et al., 2013). When compared with bibliographical data (Table 3), values measured in deeper-dwelling organisms are higher than values for individuals of the same species captured at shallower sites. We propose some hypotheses to explain this trend, on the basis of biotic and abiotic factors.

From a biological point of view, an effect of depth on growth rate and longevity of organisms was demonstrated (Drazen and Haedrich, 2012). Due to decreasing amount and nutritive quality of OM with depth (Heussner et al., 2006), food supply to deep trophic webs decreases, which affects all organisms in the trophic web by slowing their growth. For a given similar size, deeper organisms would appear to be older than shallow ones and to have been exposed to contamination during a longer time. It would be analogous to what was observed for hake between the oligotrophic Mediterranean and the eutrophic Bay of Biscay (Cossa et al., 2012).

Some recently described features of the biogeochemical cycle of $\mathrm{Hg}$ in marine waters can also be proposed to explain the high concentrations observed in teleosts and sharks considered in this work (Blum et al., 2013; Cossa, 2013; Cossa et al., 2009). Using stable $\mathrm{Hg}$ isotopes $\left({ }^{199} \mathrm{Hg},{ }^{201} \mathrm{Hg}\right.$ and ${ }^{202} \mathrm{Hg}$ ), Blum et al (2013) confirmed that the main source of $\mathrm{MeHg}$ in the open ocean is the bacterial methylation in minimum oxygen zones (Fig. 6). Even if methylation can occur in shallow waters or at the sediment water interface, the majority of the $\mathrm{MeHg}$ (60 to $80 \%$ ) is formed in low oxygen water, where heterotrophic bacterial activity is at a maximum (Cossa et al., 2009). On the contrary, bacterial demethylation is low in deep marine zones (Blum et al., 2013). MeHg can then be adsorbed on sinking particles and be integrated in the deep trophic webs. These particles represent the main source of $\mathrm{OM}$ for organisms considered in this work, as confirmed by their $\delta^{13} \mathrm{C}$ values. These particles are also the main carrier of $\mathrm{MeHg}$, and contaminated the trophic web leading to teleosts and sharks. In addition, part of this OM (and the MeHg adsorbed upon it) can also be buried, as confirmed by the high $\mathrm{Hg}$ concentrations observed in sediments (Heimbürger et al., 2012). Several benthic or burrowing species, such as crustaceans (e.g. Alpheus spp., Calocaris macandrae) or teleosts (e.g. Lesuerigobius spp.) were important prey for the teleosts and sharks considered in this work (Macpherson, 1981; Morte et al., 2002). Consequently, the $\mathrm{Hg}$ pool in 
sediment would represent a second source of contamination, increasing the exposure for benthic fish species.

This hypothesis can also explain the discrepancy between $M$. poutassou trophic level, diet and low $\mathrm{Hg}$ concentration. This species is considered to have a similar trophic level to other teleosts and sharks sampled in this work (Fanelli et al. 2013; Macpherson, 1981; Papiol et al. 2013; Stergiou and Karpouzi, 2002;), as confirmed by its $\delta^{15} \mathrm{~N}$ values. However, M. poutassou exhibited the lowest $\mathrm{Hg}$ concentrations, with no individuals observed above health safety level. M. poutassou is generally considered as a bathypelagic species, whereas others are demersal or bathydemersal (Froese and Pauly, 2013). The main preys of M. poutassou belong to the pelagic food chain, such as krill Meganyctiphanes norvegica or lampfish Notoscopelus elongatus (Macpherson, 1981). It could thus be considered that $M$. poutassou is able to feed on the pelagic trophic web and is less influenced by the $\mathrm{Hg}$ methylated in the thermohalocline zone. As all species depend on the same OM source (phytoplanktonic production in the euphotic zone) and occupy a similar trophic level, they exhibited similar $\delta^{13} \mathrm{C}$ and $\delta^{15} \mathrm{~N}$ ratios regardless of their depth range. But, as M. poutassou would appear to feed above the methylation zone, it would be less contaminated than other species. Those results would be consistent with the findings of Choy et al (2009) who observed an effect of the depth of foraging on the $\mathrm{Hg}$ concentration in some pelagic species. Such a trend (similar trophic position but lower Hg content) was observed for M. poutassou in the Bay of Biscay, suggesting that this discrepancy is not specific to the Mediterranean Sea (Chouvelon et al., 2012). Like all pelagic or bathypelagic species, $M$. poutassou is a fast-growing species, as confirmed by its growth parameters (Froese and Pauly, 2013). The effect of a lower foraging depth would thus be amplified by a dilution of $\mathrm{Hg}$ contamination with a faster growth.

\section{Conclusions}

Our results confirmed that high $\mathrm{Hg}$ concentrations occur in deep Mediterranean organisms and that feeding is the main source of $\mathrm{Hg}$ contamination for teleosts and sharks. By elucidating the main source of $\mathrm{OM}$ at the base of the trophic webs of the continental slope, this work determined that falling OM of phytoplanktonic origin is the main source of organic matter and also of $\mathrm{Hg}$ to the trophic webs of the continental slope.. Since the teleost and shark species considered in this work are top predators, the biomagnification of $\mathrm{MeHg}$ through the food webs greatly impacted their $\mathrm{Hg}$ concentrations. Finally, several specificities of those ecosystems, such as food scarcity or the influence of depth on several biological parameters, call for a better assessment of these parameters, such as growth or age, to better assess the risks of Hg contamination.

\section{Acknowledgements}

Financial support for this work was provided by the "Agence de l'Eau Rhône Méditerranée Corse" for the RETROMED program. We are grateful to the crew of RV "L'Europe" and to Christophe Ravel for their help with sampling during the MEDITS campaign. Carbon and nitrogen stable isotope analyses were performed at the "Plateforme de Spectrometrie Isotopique", LIENSs Laboratory (CNRS - University of La Rochelle) by Pierre Richard, Benoît Lebreton and Gaël Guillou to whom we are grateful. We would also like to thank two authors who positively responded to our data requests: Mireille Harmelin-Vivien (data gathered during the MERLUMED program) and Pierina Viscaino. We are grateful to Patrick Lespagnol (Système d'Information Halieutique IFREMER) who provided us with landing statistics for these species. English corrections to an 
earlier version of the manuscript were done by Michael Paul, a native English speaker. We are grateful to three anonymous reviewers and editor for their most valuables comments on a previous version of the manuscript.

\section{References}

Andre J, Boudou A, Ribeyre F, Bernhard M. Comparative study of mercury accumulation in dolphins (Stenella coeruleoalba) from French Atlantic and Mediterranean coasts. Science of The Total Environment 1991; 104: 191-209.

Arcos J, Ruiz Y, Bearhop S, Furness R. Mercury levels in seabirds and their fish preys at the Ebro Delta (NW Mediterranean): the role of trawler discards as a source of contamination. Marine Ecology Progress Series 2002; 232: 281-290.

Aston SR, Fowler SW. Mercury in the open Mediterranean: evidence of contamination? Science of the Total Environment 1985; 43: 13-26.

Bertrand JA, De Sola LG, Papaconstantinou C, Relini G, Souplet A. The general specifications of the MEDITS surveys. Scientia Marina 2002; 66: 9-17.

Bloom N. On the chemical form of mercury in edible fish and marine invertebrate tissue. Canadian Journal of Fisheries and Aquatic Science 1992; 49: 1010-1017.

Blum JD, Popp BN, Drazen JC, Choy CA, Johnson MW. Methylmercury production below the mixed layer in the North Pacific Ocean. Nature Geoscience 2013; 6: 879-884.

Bosc E, Bricaud A, Antoine D. Seasonal and interannual variability in algal biomass and primary production in the Mediterranean Sea, as derived from 4 years of SeaWiFS observations. Global Biogeochemical Cycles 2004; 18: GB1005.

Canals M, Company JB, Martín D, Sànchez-Vidal A, Ramírez-Llodrà E. Integrated study of Mediterranean deep canyons: Novel results and future challenges. Progress in Oceanography 2013; 118: 1-27.

Canals M, Puig P, Durrieu de Madron X, Heussner S, Palanques A, Fabres J. Flushing submarine canyons. Nature 2006; 444: 354-357.

Carlier A, Riera P, Amouroux J-M, Bodiou J-Y, Grémare A. Benthic trophic network in the Bay of Banyuls-sur-Mer (northwest Mediterranean, France): An assessment based on stable carbon and nitrogen isotopes analysis. Estuarine, Coastal and Shelf Science 2007; 72: 115.

Carrassón M, Stefanescu C, Cartes J. Diets and bathymetric distributions of two bathyal sharks of the Catalan deep sea (western Mediterranean). Marine Ecology Progress Series 1992; 82: 21-30.

Chouvelon T, Spitz J, Cherel Y, Caurant F, Mendez-Fernandez P, Autier J, et al. Enhanced bioaccumulation of mercury in deep-sea fauna from the Bay of Biscay (North-East Atlantic) in relation to trophic position identified by analysis of carbon and nitrogen stable isotopes. Deep Sea Research I 2012: 113-124.

Choy CA, Popp BN, Kaneko J, Drazen JC. The influence of depth on mercury levels in pelagic fishes and their preys. Proceedings of the National Academy of Sciences 2009; 106: 1386513869. 
Cossa D. Marine biogeochemistry: Methylmercury manufacture. Nature Geoscience 2013; 6: 810-811.

Cossa D, Averty B, Pirrone N. The origin of methylmercury in open Mediterranean waters. Limnology and Oceanography 2009; 54: 837-844.

Cossa D, Coquery M. The Mediterranean mercury anomaly, a geochemical or a biologocal issue. In: Saliot A, editor. The Mediterranean sea. Handbook of environmental chemistry. 5K. Springer, 2005, pp. 177-208.

Cossa D, Garnier C, Buscail R, Elbaz-Poulichet F, Mikac N, Patel-Sorrentino N, et al. A Michaelis-Menten type equation for describing methylmercury dependence on inorganic mercury in aquatic sediments. Biogeochemistry 2013: 1-9.

Cossa D, Harmelin-Vivien M, Mellon-Duval C, Loizeau V, Averty B, Crochet S, et al. Influence of bioavailability, trophic position, and growth on methylmercury in hakes (Merluccius merluccius) from Northwestern Mediterranean and Northeast Atlantic. Environmental Science and Technology 2012; 46: 4885-4893.

Cresson P, Ruitton S, Fontaine M-F, Harmelin-Vivien M. Spatio-temporal variation of suspended and sedimentary organic matter quality in the Bay of Marseilles (NW Mediterranean) assessed by biochemical and isotopic analyses. Marine Pollution Bulletin 2012; 64: 1112-1121.

Cresson P, Ruitton S, Ourgaud M, Harmelin-Vivien M. Contrasting perception of fish trophic level from stomach content and stable isotope analyses: A Mediterranean artificial reef experience. Journal of Experimental Marine Biology and Ecology 2014; 452: 54-62.

Cristo M, Cartes J. A comparative study of the feeding ecology of Nephrops norvegicus (L.), (Decapoda: Nephropidae) in the bathyal Mediterranean and the adjacent Atlantic. Scientia Marina 1998; 62: 81-90.

Darnaude AM, Salen-Picard C, Polunin NVC, Harmelin-Vivien M. Trophodynamic linkage between river runoff and coastal fishery yield elucidated by stable isotope data in the Gulf of Lions (NW Mediterranean). Oecologia 2004; 138: 325-332.

Della Torre C, Petochi T, Corsi I, Dinardo MM, Baroni D, Alcaro L, et al. DNA damage, severe organ lesions and high muscle levels of $\mathrm{As}$ and $\mathrm{Hg}$ in two benthic fish species from a chemical warfare agent dumping site in the Mediterranean Sea. Science of the Total Environment 2010; 408: 2136-2145.

Dierking J, Wafo E, Schembri T, Lagadec V, Nicolas C, Letourneur Y, et al. Spatial patterns in PCBs, pesticides, $\mathrm{Hg}$ and cadmium in the common sole in the NW Mediterranean, and a novel use of contaminants as a biomarker. Marine Pollution Bulletin 2009; 58: 1605-1614.

Drazen JC, Haedrich RL. A continuum of life histories in deep-sea demersal fishes. Deep Sea Research Part I: Oceanographic Research Papers 2012; 61: 34-42.

Drazen JC, Popp BN, Choy CA, Clemente T, De Forest L, Smith Jr KL. Bypassing the abyssal benthic food web: Macrourid diet in the eastern North Pacific inferred from stomach content and stable isotopes analyses. Limnology and Oceanography 2008; 53: 2644-2654.

Durrieu de Madron X, Guieu C, Sempéré R, Conan P, Cossa D, D'Ortenzio F, et al. Marine ecosystems' responses to climatic and anthropogenic forcings in the Mediterranean. Progress in Oceanography 2011; 91: 97-166.

EC. Commision regulation (EC) No 1881/2006 of 19 December 2006 setting maximum levels for certain contaminants in foodstuffs (Text with EEA relevance), 2006. 
Fabri MC, Pedel L, Beuck L, Galgani F, Hebbeln D, Freiwald A. Megafauna of vulnerable marine ecosystems in French mediterranean submarine canyons: Spatial distribution and anthropogenic impacts. Deep Sea Research Part II: Topical Studies in Oceanography 2014; 104: 184-207.

Fanelli E, Papiol V, Cartes J, Rumolo P, Brunet C, Sprovieri M. Food web structure of the epibenthic and infaunal invertebrates on the Catalan Slope (NW Mediterranean): evidence from $\delta^{13} \mathrm{C}$ and $\delta^{15} \mathrm{~N}$ analyses. Deep Sea Research I 2011; 50: 98-109.

Fanelli E, Papiol V, Cartes J, Rumolo P, López-Pérez C. Trophic webs of deep-sea megafauna on mainland and insular slopes of the NW Mediterranean: a comparison by stable isotope analysis. Marine Ecology Progress Series 2013; 490: 199-221.

Fanelli E, Rey J, Torres P, Gil de Sola L. Feeding habits of blackmouth catshark Galeus melastomus Rafinesque, 1810 and velvet belly lantern shark Etmopterus spinax (Linnaeus, 1758 ) in the western Mediterranean. Journal of Applied Ichthyology 2009; 25: 83-93.

Fitzgerald W, Clarkson T. Mercury and monomethylmercury: present and future concerns: present and future concern. Environmental Health Perspectives 1991; 96: 159-166.

Fitzgerald WF, Lamborg CH. 9.04 - Geochemistry of Hg in the Environment. In: Holland HD, Turekian KK, editors. Treatise on Geochemistry. Pergamon, Oxford, 2007, pp. 1-47.

Froese R, Pauly D. FishBase.World Wide Web electronic publication. www.fishbase.org., 2013.

Hall BD, Bodaly RA, Fudge RJP, Rudd JWM, Rosenberg DM. Food as the Dominant Pathway of Methylmercury Uptake by Fish. Water, Air, and Soil Pollution 1997; 100: 13-24.

Halpern BS, Walbridge S, Selkoe KA, Kappel CV, Micheli F, D'Agrosa C, et al. A Global Map of Human Impact on Marine Ecosystems. Science 2008; 319: 948-952.

Harmelin-Vivien M, Bodiguel X, Charmasson S, Loizeau V, Mellon-Duval C, Tronczyński J, et al. Differential biomagnification of PCB, PBDE, $\mathrm{Hg}$ and Radiocesium in the food web of the European hake from the NW Mediterranean. Marine Pollution Bulletin 2012; 64: 974-983.

Harmelin-Vivien M, Cossa D, Crochet S, Bănaru D, Letourneur Y, Mellon-Duval C. Difference of $\mathrm{Hg}$ bioaccumulation in red mullets from the north-western Mediterranean and Black seas. Marine Pollution Bulletin 2009; 58: 679-685.

Harmelin-Vivien M, Dierking J, Bănaru D, Fontaine M-F, Arlhac D. Seasonal variation in stable $\mathrm{C}$ and $\mathrm{N}$ isotope ratios of the Rhone River inputs to the Mediterranean Sea (2004-2005). Biogeochemistry 2010; 100: 139-150.

Harmelin-Vivien M, Loizeau V, Mellon C, Beker D, Arlhac D, Bodiguel X, et al. Comparison of C and $\mathrm{N}$ stable isotope ratios between surface particulate organic matter and microphytoplankton in the Gulf of Lions (NW Mediterranean). Continental Shelf Research 2008; 28: 1911-1918.

Heimbürger LE, Cossa D, Marty JC, Migon C, Averty B, Dufour A, et al. Methyl mercury distribution in relation to the presence of nano- and picophytoplankton in an oceanic water column (Ligurian Sea, North-western Mediterranean). Geochemica et Cosmochimica Acta 2010; 74: 5549-5559.

Heimbürger LE, Cossa D, Thibodeaud B, Khripounoff A, Mas V, Chiffoleau J, et al. Natural and anthropogenic trace metals in sediment of the Ligurian Sea (Northwestern Mediterranean). Chemical Geology 2012; 291: 141-151. 
Heussner S, Durrieu de Madron X, Calafat A, Canals M, Carbonne J, Delsaut N, et al. Spatial and temporal variability of downwards particle fluxes on a continental slope: Lessons from a 8-yr experiment in the Gulf of Lions (NW Mediterranean). Marine Geology 2006; 234: 63-92.

Hoffman J, Sutton T. Lipid correction for carbon stable isotope analysis of deep-sea fishes. Deep Sea Research I 2010; 57: 956-964.

Hornhung $\mathrm{H}$, Krom M, Cohen $\mathrm{Y}$, Bernhard M. Trace metal content in deep-water sharks from the eastern Mediterranean Sea. Marine Biology 1993; 115: 331-338.

Hussey NE, MacNeil MA, McMeans BC, Olin JA, Dudley SF, Cliff G, et al. Rescaling the trophic structure of marine food webs. Ecology Letters 2014; 17: 239-250.

Koenig S, Solé M, Fernández-Gómez C, Díez S. New insights into mercury bioaccumulation in deep-sea organisms from the NW Mediterranean and their human health implications. Science of The Total Environment 2013; 442: 329-335.

Lopez-Fernandez P, Bianchelli S, Pusceddu A, Calafat A, Danovaro R, Canals M. Bioavailable compounds in sinkings particulate organic matter, Blanes Canyon, NW Mediterranean Sea: Effect of large storm and sea surface biological processes. Progress in Oceanography 2013; 118: 108-121.

Macpherson E. Régimen alimentario de Phycis blennoides (Brünich) y Antonogadus megalokynodon (Kolombatovic) (Pisces: Gadidae) en el Méditerraneo occidental. Investigacion Pesquera 1978; 42: 455-466.

Macpherson E. Estudio sobre el regimen alimentatio de algunos peces en el Mediterraneo occidental. Miscellania zoológica 1979; 1979: 93-107.

Macpherson E. Ressource partitionning in a Mediterranean demersal fish community. Marine Ecology Progress Series 1981; 4: 183-193.

Magalhães MC, Costa V, Menezes GM, Pinho MR, Santos RS, Monteiro LR. Intra- and interspecific variability in total and methylmercury bioaccumulation by eight marine fish species from the Azores. Marine Pollution Bulletin 2007; 54: 1654-1662.

Mellon-Duval C, de Pontual H, Métral L, Quemener L. Growth of European hake (Merluccius merluccius) in the Gulf of Lions based on conventional tagging. ICES Journal of Marine Science 2010; 67: 62-70.

Mill AC, Pinnegar JK, Polunin NVC. Explaining isotope trophic-step fractionation: why herbivorous fish are different. Functional Ecology 2007; 21: 1137-1145.

Morat F, Letourneur Y, Dierking J, Pécheyran C, Bareille G, Blamart D, et al. The Great Melting Pot. Common Sole Population Connectivity Assessed by Otolith and Water Fingerprints. Plos One 2014; 9: e86585.

Morel F, Kraepiel A, Amyot M. The chemical cycle and bioaccumulation of mercury. Annual Review of Ecology and Systematics 1998: 29.

Morte M, Redon MJ, Sanz-Brau A. Diet of Phycis blennoides (Gadidae) in relation to fish size and season in the Western Mediterranean (Spain). P.S.Z. N. I: Marine Ecology 2002; 23: 141-155.

Nakhlé K, Cossa D, Claisse D, Beliaeff B, Simon S. Cadmium and mercury in Seine Estuary flounders and muscle: the results of two decades of monitoring. ICES Journal of Marine Science 2007; 64: 929-938. 
Papiol V, Cartes JE, Fanelli E, Rumolo P. Food web structure and seasonality of slope megafauna in the NW Mediterranean elucidated by stable isotopes: Relationship with available food sources. Journal of Sea Research 2013; 77: 53-69.

Pasqual C, Goñi MA, Tesi T, Sanchez-Vidal A, Calafat A, Canals M. Composition and provenance of terrigeneous organic matter transported along submarine canyons in the Gulf of Lions (NW Mediterranean Sea). Progress in Oceanography 2013; 118: 81-94.

Perrugini M, Visciano P, Manera M, Zaccaroni A, Olivieri V, Amorena M. Levels of total mercury in marine organisms from Adriatic Sea, Italy. Bulletin of Environmental Contamination and Toxicology 2009; 83: 244-248.

Perrugini M, Visciano P, Manera M, Zaccaroni A, Olivieri V, Amorena M. Heavy metals (As, Cd, $\mathrm{Hg}, \mathrm{Pb}, \mathrm{Cu}, \mathrm{Zn}, \mathrm{Se}$ ) concentrations in muscle and bone of four commercial fish caught in the central Adriatic Sea, Italy. Environmental Monitoring and Assesment 2013: 1-9.

Pethybridge $\mathrm{H}$, Cossa D, Butler ECV. Mercury in 16 demersal sharks from Southern Australia: Biotic and abiotic sources of variations and consumer health implication. Marine Environmental Research 2010; 69: 18-26.

Pickhardt $\mathrm{P}$, Fisher $\mathrm{N}$. Accumulation of inorganic and methylmercury by freshwater phytoplankton in two contrasting water bodies. Environmental Science and Technology 2007; 41: 125-131.

Pinnegar JK, Polunin NVC. Differential fractionation of $\delta^{13} \mathrm{C}$ and $\delta^{15} \mathrm{~N}$ among fish tissues : implication for the study of trophic interactions. Functional Ecology 1999; 13: 225-231.

Polunin NVC, Morales-Nin B, Pawsey W, Cartes J, Pinnegar J, Moranta J. Feeding relationships in Mediterranean bathyal assemblages elucidated by stable and nitrogen carbon isotope data. Marine Ecology Progress Series 2001; 220: 13-23.

Sanchez-Vidal A, Higueras M, Martí E, Liquete C, Calafat A, Kerhervé $P$, et al. Riverine transport of terrestrial organic matter to the North Catalan margin, NW Mediterranean Sea. Progress in Oceanography 2013; 118: 71-80.

Sanchez-Vidal A, Pasqual C, Kerhervé P, Heussner S, Calafat A, Palanques A, et al. Across margin export of organic matter by cascading events traced by stable isotopes, northwestern Mediterranean Sea. Limnology and Oceanography 2008; 54: 1488-1500.

Scheuhammer AM, Meyer MW, Sandheinrich MB, Murray MW. Effects of Environmental Methylmercury on the Health of Wild Birds, Mammals, and Fish. AMBIO: A Journal of the Human Environment 2007; 36: 12-19.

Stergiou KI, Karpouzi VS. Feeding habits and trophic levels of Mediterranean fish. Reviews in Fish Biology and Fisheries 2002; 11: 217-254.

Storelli MM. Intake of Essential Minerals and Metals via Consumption of Seafood from the Mediterranean Sea. Journal of Food Protection 2009; 72: 1116-1120.

Storelli MM, Barone G. Toxic Metals ( $\mathrm{Hg}, \mathrm{Pb}$, and $\mathrm{Cd}$ ) in Commercially Important Demersal Fish from Mediterranean Sea: Contamination Levels and Dietary Exposure Assessment. Journal of Food Science 2013; 78: T362-T366.

Storelli MM, Barone G, Piscitelli G, Marcotrigiano GO. Mercury in fish: concentration vs. fish size and estimates of $\mathrm{Hg}$ intake. Food Additives and Contaminants 2007; 24: 1353 - 1357.

Storelli MM, Busco VP, Marcotrigiano GO. Mercury and Arsenic speciation in muscle tissue of Scyliorhinus canicula from the Mediterranean Sea. Bulletin of Environmental Contamination and Toxicology 2005; 75: 81-88. 
Storelli MM, Giacominelli-Stuffler R, Marcotrigiano GO. Mercury accumulation and speciation in muscle tissue of different species of shark from Mediterranean Sea, Italy. Bulletin of Environmental Contamination and Technology 2002; 68: 201-210.

Streets D, Devane M, Lu Z, Bond T, Sunderland E, Jacob D. All-time releases of mercury to the atmosphere from human activities. Environmental Science and Technology 2011; 45: 10485-10491.

Tartu S, Goutte A, Bustamante P, Angelier F, Moe B, Clément-Chastel C, et al. To breed or not to breed: endocrine response to mercury contamination by an Arctic seabird. Biology letters 2013; 9: 20130317.

Tecchio S, Coll M, Christensen V, Ramírez-Llodra E, Sardà F. Food web structure and vulnerability of a deep-sea ecosystem in the NW Mediterranean Sea. Deep Sea Research Part I: Oceanographic Research Papers 2013.

Tesi T, Miserocchi S, Goñi MA, Langone L, Boldrin A, Turchetto M. Organic matter origin and distribution in suspended particulate materials and superficial sediments from the western Adriatic Sea (Italy). Estuarine, Coastal and Shelf Science 2007; 73: 431-446.

Thibaud $Y$. Teneurs en mercure de quelques poissons de consommation courante. Sciences et Pêches, Bulletin de l'Institut des pêches maritimes 1971; 206: 1-10.

UNEP. Global mercury assessment 2013: Sources, emissions, releases and environmental transport, UNEP Chemical branch, Geneva, Switzerland, 2013, pp. 32.

Wyatt ASJ, Waite AM, Humphries S. Variability in isotope discrimination factors in coral reef fishes: Implications for diet and food web reconstruction. Plos One 2010; 5: e13682. 


\section{Tables}

Table 1: Number of individuals, total length (mean, standard deviation, minimum and maximum values), stable isotope ratios (mean and standard deviation), mean $\mathrm{C} / \mathrm{N}$ ratio (mean and standard deviation), and $\mathrm{Hg}$ concentration (mean, standard deviation and maximum value). For Nephrops norvegicus, length refers to cephalothorax length. Detailed results obtained on each site for all species are presented inTable S1.

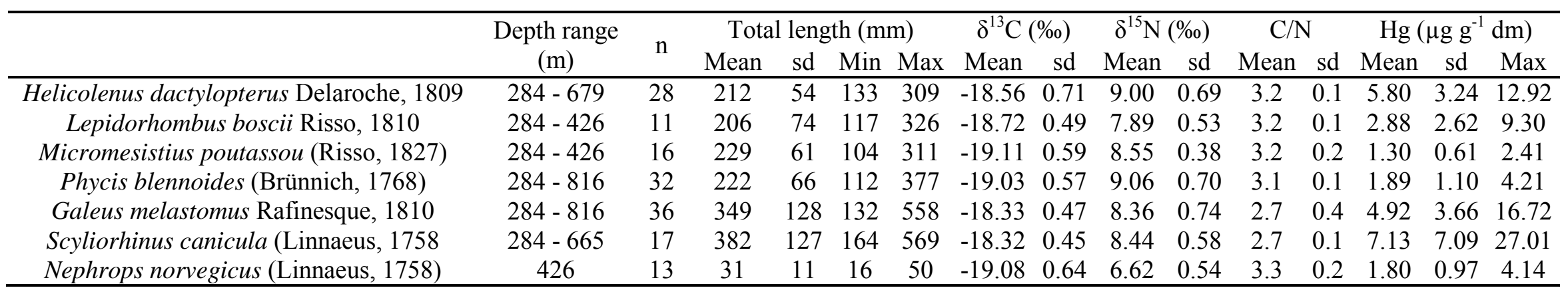


Table 2: Spatial variability of isotopic ratios and $\mathrm{Hg}$ concentrations for each species. Comparisons were performed with ANCOVA when a significant correlation between the studied parameter and length was observed. Test was run on log-transformed data if the best fit was observed with exponential regression or on untransformed data when linear regression was the best fit. If no significant correlation was observed, test was run with Kruskal-Wallis test, as normality prerequisite was not reached. See Tables S1 and S2 for detailed parameters of the regressions. Post hoc column presents significant differences between sampling depths. Signif: significance level of the test (***: $p$-value $\leq 0.001 ;{ }^{* *}$ : $p$-value $\leq 0.01{ }^{*}$ : $p$-value $\leq 0.05$; ns: non-significant, $p$-value>0.05). Species names are abbreviated with the initial letter of their genus and species (Gm: Galeus melastomus; Hd: Helicolenus dactylopterus; Lb: Lepidorhombus boscii; Mp: Micromesistius poutassou; Pb: Phycis blennoides; Sc: Scyliorhinus canicula)

\begin{tabular}{|c|c|c|c|c|c|c|}
\hline Parameter & Species & Test & dataset & Statistics & Signif. & post hoc (sampling depths) \\
\hline \multirow[t]{6}{*}{$\delta^{13} \mathrm{C}(\%)$} & $\mathrm{Gm}$ & ANCOVA & untransf. & $\mathrm{F}_{(4,30)}=0.48$ & ns & \multirow{4}{*}{$426 \mathrm{~m}=284 \mathrm{~m}<369 \mathrm{~m}<679 \mathrm{~m}$} \\
\hline & $\mathrm{Hd}$ & ANCOVA & untransf. & $F_{(3,23)}=7.66$ & $* * *$ & \\
\hline & $\mathrm{Lb}$ & ANCOVA & untransf. & $\mathrm{F}_{(1,8)}=0.04$ & ns & \\
\hline & $\mathrm{Mp}$ & ANCOVA & untransf. & $\mathrm{F}_{(1,13)}=1.40$ & ns & \\
\hline & $\mathrm{Pb}$ & ANCOVA & untransf. & $\mathrm{F}_{(4,26)}=4.78$ & $* *$ & \multirow[t]{2}{*}{$284 \mathrm{~m}=426 \mathrm{~m}<816 \mathrm{~m}=679 \mathrm{~m}=665 \mathrm{~m}$} \\
\hline & $\mathrm{Sc}$ & ANCOVA & untransf. & $F_{(2,13)}=2.67$ & ns & \\
\hline \multirow[t]{6}{*}{$\delta^{15} \mathrm{~N}(\%)$} & $\mathrm{Gm}$ & ANCOVA & log-transf. & $\mathrm{F}_{(4,30)}=1.44$ & ns & \multirow{6}{*}{$284 \mathrm{~m}=426 \mathrm{~m}=369 \mathrm{~m}<679 \mathrm{~m}$} \\
\hline & $\mathrm{Hd}$ & KW & untransf & $\mathrm{H}_{(3,28)}=11.58$ & $*$ & \\
\hline & $\mathrm{Lb}$ & ANCOVA & untransf & $\mathrm{F}_{(1,8)}=2,33$ & ns & \\
\hline & $\mathrm{Mp}$ & ANCOVA & log-transf. & $\mathrm{F}_{(1,13)}=0.48$ & $\mathrm{~ns}$ & \\
\hline & $\mathrm{Pb}$ & ANCOVA & untransf & $\mathrm{F}_{(4,26)}=0.66$ & ns & \\
\hline & $\mathrm{Sc}$ & ANCOVA & untransf & $\mathrm{F}_{(2,13)}=0.41$ & ns & \\
\hline & $\mathrm{Gm}$ & ANCOVA & log-transf. & $\mathrm{F}_{(4,30)}=1.51$ & ns & \multirow{4}{*}{$284 \mathrm{~m}=426 \mathrm{~m}=369 \mathrm{~m}<679 \mathrm{~m}$} \\
\hline \multirow[t]{5}{*}{$\left(\mu \mathrm{g} \mathrm{g}^{-1} \mathrm{dm}\right)$} & $\mathrm{Hd}$ & ANCOVA & untransf & $\mathrm{F}_{(3,23)}=10.44$ & $* * *$ & \\
\hline & $\mathrm{Lb}$ & ANCOVA & log-transf. & $F_{(1,8)}=2,33$ & ns & \\
\hline & $\mathrm{Mp}$ & ANCOVA & log-transf. & $\mathrm{F}_{(1,13)}=2.29$ & ns & \\
\hline & $\mathrm{Pb}$ & ANCOVA & untransf & $F_{(4,26)}=3.90$ & $*$ & \multirow[t]{2}{*}{$284 \mathrm{~m}=426 \mathrm{~m}<816 \mathrm{~m}=679 \mathrm{~m}=665 \mathrm{~m}$} \\
\hline & Sc & ANCOVA & log-transf. & $F_{(2,13)}=1.28$ & ns & \\
\hline
\end{tabular}


Table 3: Mean Hg concentrations recorded in bibliographical references in the Mediterranean Sea. When available, data on depth or length were collected from the paper or from the authors (as denoted by an asterisk after the data). If needed, wet mass were converted to dry mass using the equation dry mass $=5$ wet mass. For Nephrops norvegicus, length refers to cephalothorax length.

\begin{tabular}{|c|c|c|c|c|c|c|c|}
\hline \multirow[t]{2}{*}{ Species } & \multirow[t]{2}{*}{ Sampling location } & \multirow[t]{2}{*}{ Depth (m) } & \multicolumn{2}{|c|}{$\begin{array}{l}\mathrm{Hg} \text { concentration } \\
\left(\mu \mathrm{g} \mathrm{g}^{-1} \mathrm{dm}\right)\end{array}$} & \multirow[t]{2}{*}{$\mathrm{n}$} & \multirow{2}{*}{$\begin{array}{l}\text { Length }(\mathrm{mm}) \\
\text { Mean } \pm \mathrm{sd}\end{array}$} & \multirow[t]{2}{*}{ Reference } \\
\hline & & & Mean \pm sd & Max & & & \\
\hline Helicolenus & Gulf of Lions & $284-679$ & $5.80 \pm 3.24$ & 12.92 & 28 & $214 \pm 54$ & present study \\
\hline \multirow[t]{3}{*}{ dactylopterus } & Adriatic Sea & nd & $1.04 \pm 0.56$ & 1.90 & 243 & $180 \pm 50$ & Storelli and Barone (2013) \\
\hline & Adriatic Sea ${ }^{a}$ & $200-300$ & $2.23 \pm 0.22$ & nd & 20 & $311 \pm 38$ & Della Tore et al (2010) \\
\hline & Adriatic Sea & nd & $3.10 \pm 1.00$ & 9.2 & 40 & nd & Storelli (2009) \\
\hline Lepidorhombus & Gulf of Lions & $284-426$ & $2.88 \pm 2.62$ & 9.30 & 11 & $206 \pm 74$ & present study \\
\hline boscii & Adriatic Sea & nd & $1.85 \pm 0.95$ & 2.7 & 40 & nd & Storelli (2009) \\
\hline Micromesistius & Gulf of Lions & $284-426$ & $1.30 \pm 0.61$ & 2.41 & 16 & $207 \pm 67$ & present study \\
\hline \multirow[t]{3}{*}{ poutassou } & Gulf of Lions & $60-100 *$ & $0.27 \pm 0.31$ & $0.49 *$ & 3 & $>120 \mathrm{~mm}$ & Harmelin-Vivien et al (2012) \\
\hline & Balearic sea & nd & 0.10 & 0.13 & 34 & $142 \pm 7$ & Arcos et al. (2002) \\
\hline & Adriatic Sea & $200 *$ & $0.38 \pm 0.09$ & 1.42 & 14 & $213 \pm 30$ & Perrugini et al. (2013) \\
\hline \multirow{2}{*}{ Phycis blennoides } & Gulf of Lions & $284-816$ & $1.89 \pm 1.10$ & 4.21 & 32 & $220.7 \pm 70$ & present study \\
\hline & Adriatic Sea & nd & $0.67 \pm 0.35$ & 1.41 & 224 & 265 & Storelli et al. (2007) \\
\hline \multirow{5}{*}{ Galeus melastomus } & Gulf of Lions & $284-816$ & $4.92 \pm 3.66$ & 16.71 & 36 & $349 \pm 128$ & present study \\
\hline & Adriatic Sea (Italy) & nd & $2.66 \pm 1.14$ & 5.03 & 164 & $456 \pm 86$ & Storelli et al. (2002) \\
\hline & Adriatic Sea (Albania) & nd & $1.01 \pm 0.62$ & 2.06 & 164 & $392 \pm 98$ & Storelli et al. (2002) \\
\hline & Ionian Sea & nd & $0.82 \pm 0.62$ & 2.84 & 273 & $333 \pm 127$ & Storelli et al. (2002) \\
\hline & Levantine Sea (Israel) & $1300-1420$ & 0.99 & 8.76 & 63 & nd & Hornung et al. (1993) \\
\hline Scyliorhinus & Gulf of Lions & $284-665$ & $7.13 \pm 7.09$ & 27.01 & 17 & $382 \pm 127$ & present study \\
\hline canicula & Adriatic Sea & nd & $1.10 \pm 0.62$ & 2.06 & 12 & nd & Storelli et al. (2005) \\
\hline Nephrops & Gulf of Lions & 426 & $1.80 \pm 0.97$ & 4.14 & 13 & $31 \pm 11$ & present study \\
\hline norvegicus & Adriatic Sea & $200 *$ & $0.97 \pm 0.24$ & 3.27 & 13 & $42.6 \pm 1.8$ & Perrugini et al. (2009) \\
\hline
\end{tabular}

a: Site impacted by the dumping of chemical weapons; *: data provided by the authors, in addition with the data available in the paper cited 


\section{Figures}

Fig. 1: Position and depth of the sampling points on the French Mediterranean continental slope. The names refer to the submarine canyons. GoL: Gulf of Lions

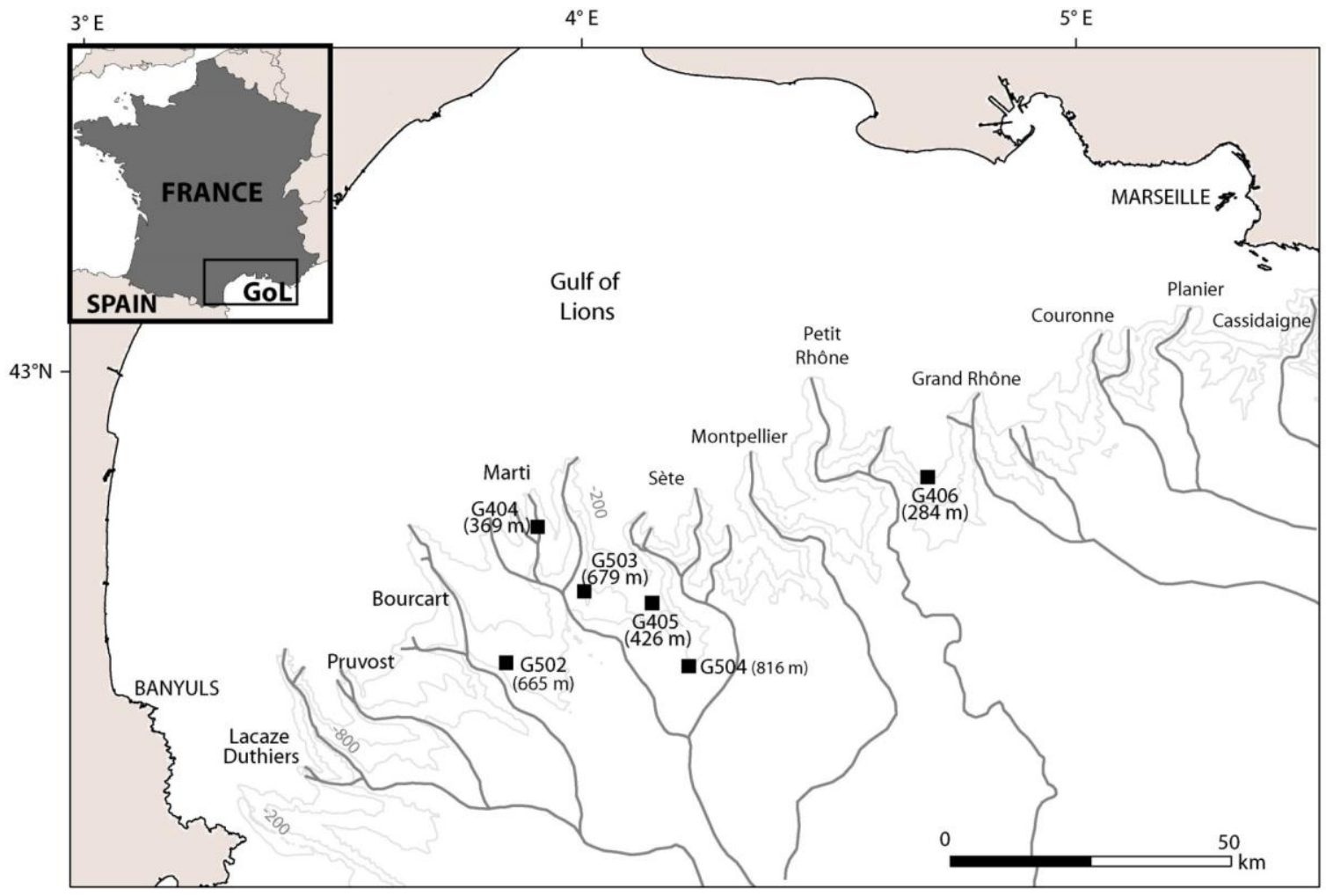


Fig. 2: Trophic positions of organisms based on their mean $\delta^{13} \mathrm{C}$ and $\delta^{15} \mathrm{~N}$ values. Range of isotopic ratios measured for the organism is presented by the large hatched zone around mean values. Range of isotopic ratios measured for the two potential OM sources is represented by small hatched squares, and is based on bibliographical data for river OM inputs (Cresson et al., 2012; Darnaude et al., 2004; Harmelin-Vivien et al., 2010; Sanchez-Vidal et al., 2013; Tesi et al., 2007) or phytoplanktonic production (Harmelin-Vivien et al., 2008). Brown and blue zones represent the zone influenced by one or the other OM source, following the relationship between diet and consumer isotopic ratios presented in the upper left corner of the figure. Names of the species are abbreviated for graphic purposes (Gal mel: Galeus melastomus; Hel dac: Helicolenus dactylopterus; Lep bos: Lepidorhombus boscii; Mic pou: Micromesistius poutassou; Nep nor: Nephrops norvegicus; Phy ble: Phycis blennoides, Scy can: Scylorhinus canicula). Results of the ANOVA mean comparison tests for the $\delta^{13} \mathrm{C}$ and $\delta^{15} \mathrm{~N}$ values are displayed on the graph and in Table S2. Please refer to the electronic version of the article for color indications.

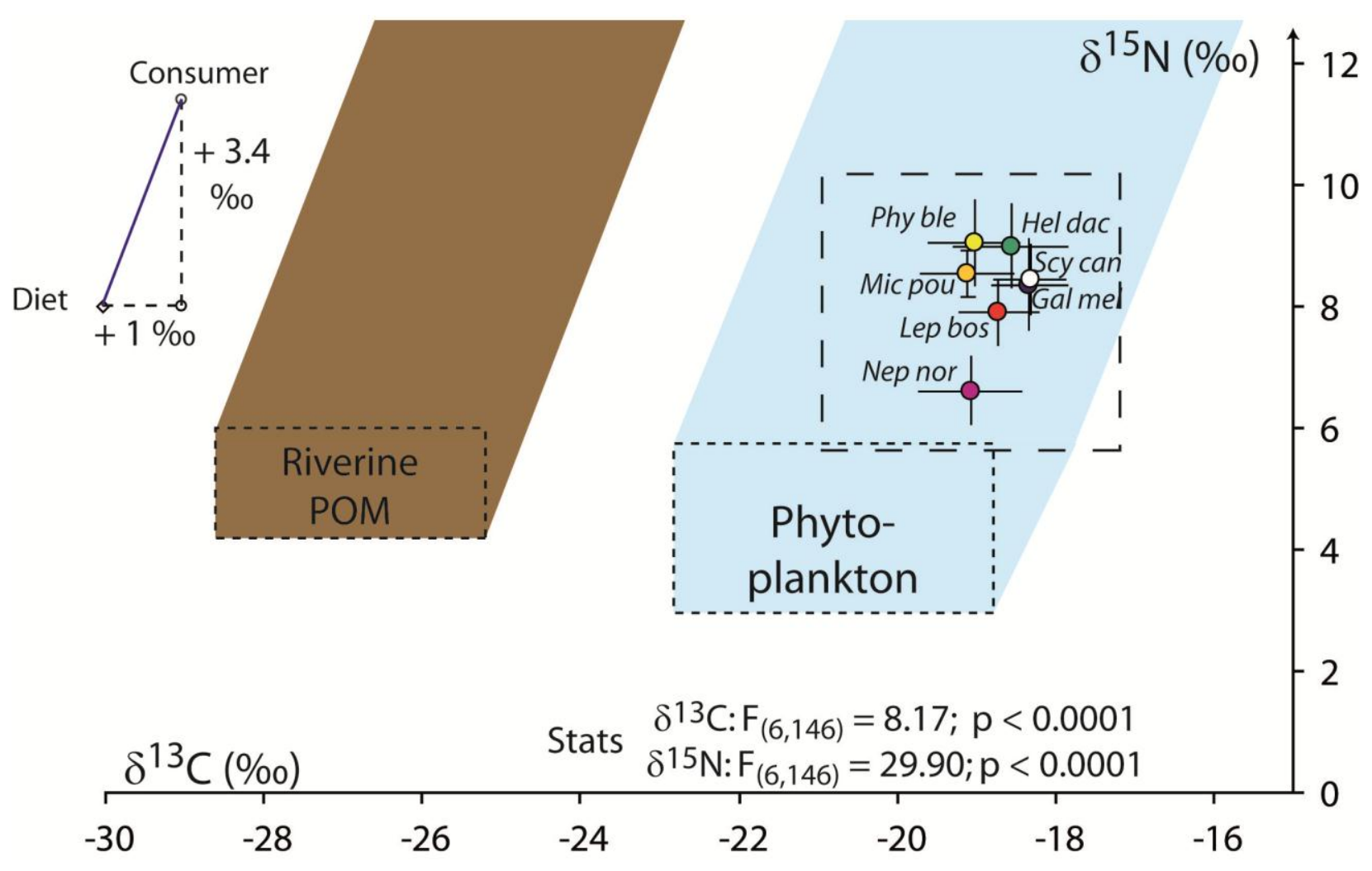


Fig. 3: Spatial comparisons of teleosts and sharks total length. Letters refer to the statistical test used (H: Kruskal-Wallis; F: ANOVA; Z: Mann Whitney). Box hinges are the $1^{\text {st }}$ and $3^{\text {rd }}$ quartiles, line is the median value, whiskers extends from the hinge to the highest or lowest value that is within $1.5 \mathrm{x}$ interquartile range. Points are outlier values.

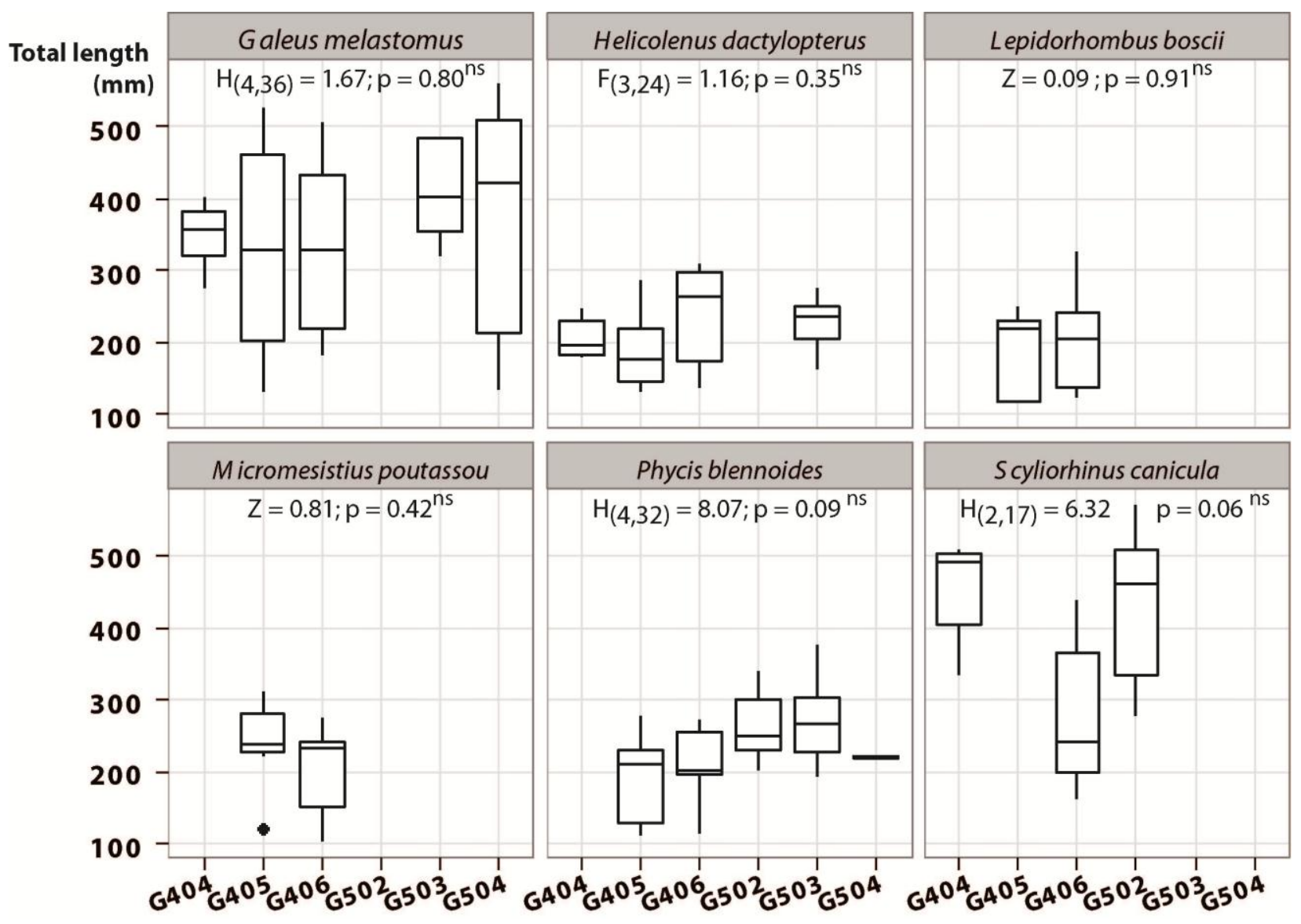


Fig. 4: Boxplots of $\mathrm{Hg}$ concentration ( $\mu \mathrm{g} \mathrm{g} \mathrm{g}^{-1}$ dry mass). Box hinges are the $1^{\text {st }}$ and $3^{\text {rd }}$ quartiles, line is the median value, whiskers extends from the hinge to the highest or lowest value that is within $1.5 \mathrm{x}$ interquartile range. Horizontal hatched lines represent the maximum levels in food stuffs established by European Commission (EC, 2006) at $2.5 \mu \mathrm{g} \mathrm{g}{ }^{-1} \mathrm{dm}$ for most teleosts, and 5 $\mu \mathrm{g} \mathrm{g}^{-1} \mathrm{dm}$ for sharks, and Lepidorhombus species (considering a conversion factor of 5 between dry and wet mass). Percentage values are the proportion of individuals whose concentration is above this value. Species with different letters exhibit significantly different $\mathrm{Hg}$ concentration.

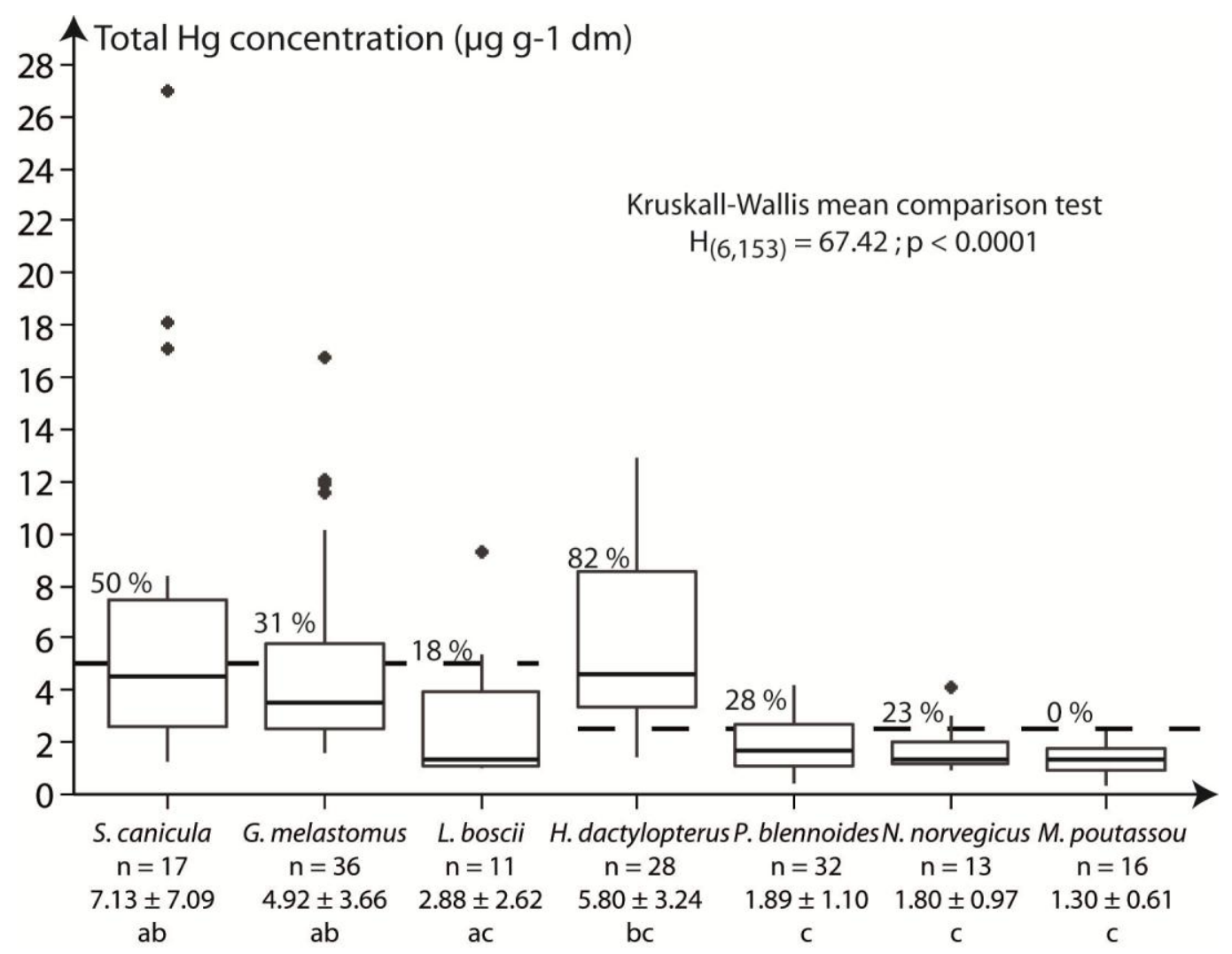


Fig. 5: Regression curves between $\mathrm{Hg}$ concentration ( $\mu \mathrm{g} \mathrm{g}{ }^{-1}$ dry mass) and total length or $\delta^{15} \mathrm{~N}$. Shape of the curves (linear or exponential) represents the best fitting model, see table S1 for details and parameters of the regressions. Non-significant regressions are not drawn. Colors are representatives of species: black, Scyliorhinus canicula, orange: Galeus melastomus, green: Lepidorhombus boscii, yellow: Helicolenus dactylopterus, light blue: Phycis blennoides, red: Micromesistius poutassou, dark blue: Nephrops norvegicus. For color indications, refer to the electronic version of the article.
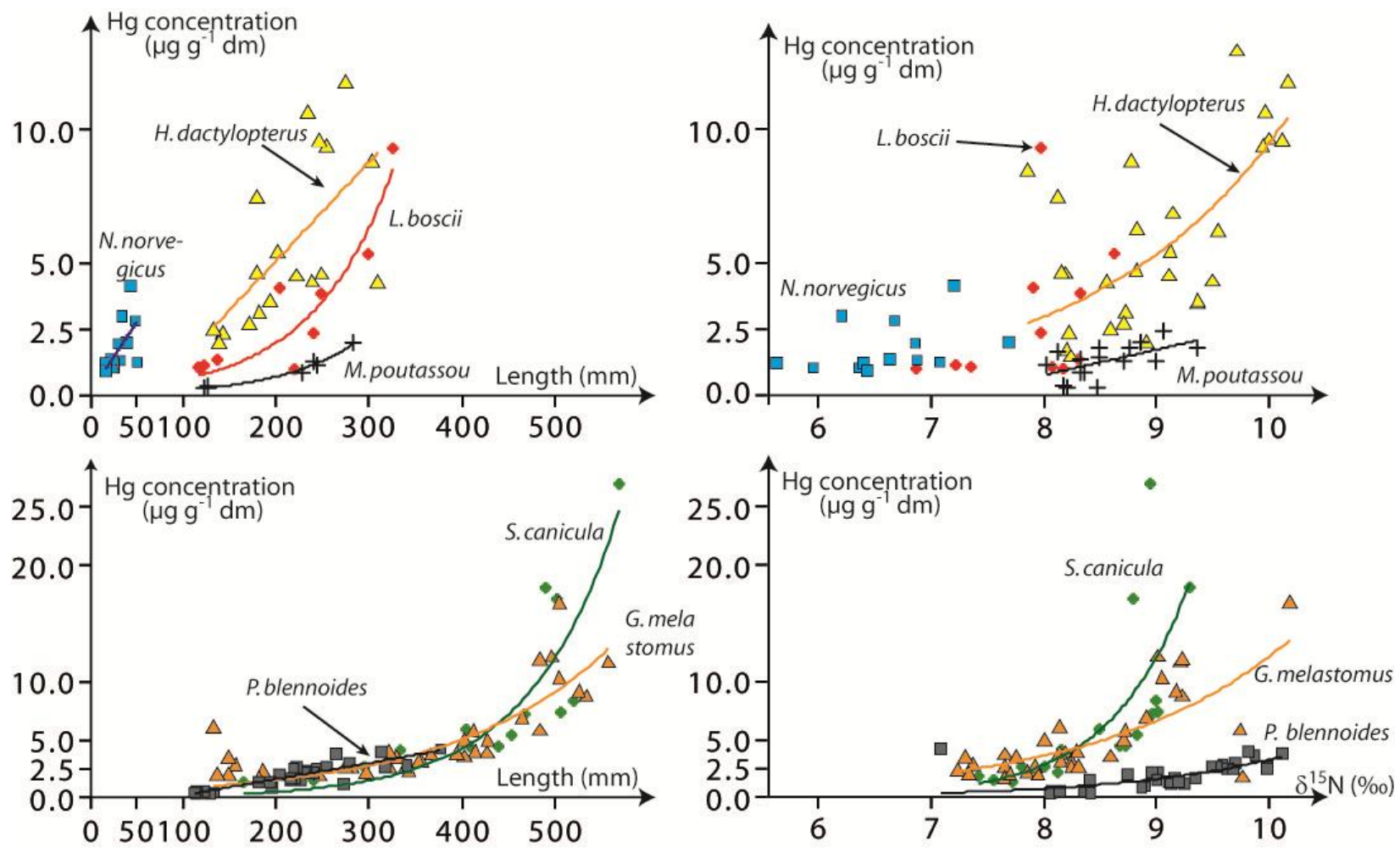
Fig 6: Schematic representation of the $\mathrm{OM}$ and $\mathrm{Hg}$ flux to trophic webs of continental slope of the Gulf of Lions, from atmospheric deposition to burial in deep sea sediments and resuspension of the sedimentary $\mathrm{OM}$ and $\mathrm{Hg}$ pool. The majority of the $\mathrm{MeHg}$ is formed in the thermohalocline zone, and is then fixed on sinking particles. Benthic organisms are dependent on sinking particles whereas $M$. poutassou is more pelagic and is able to feed on pelagic trophic webs. This representation was adapted from the work of Blum et al (2013), and was drawn with symbols courtesy of the Integration and Application Network (ian.umces.edu/symbols/).

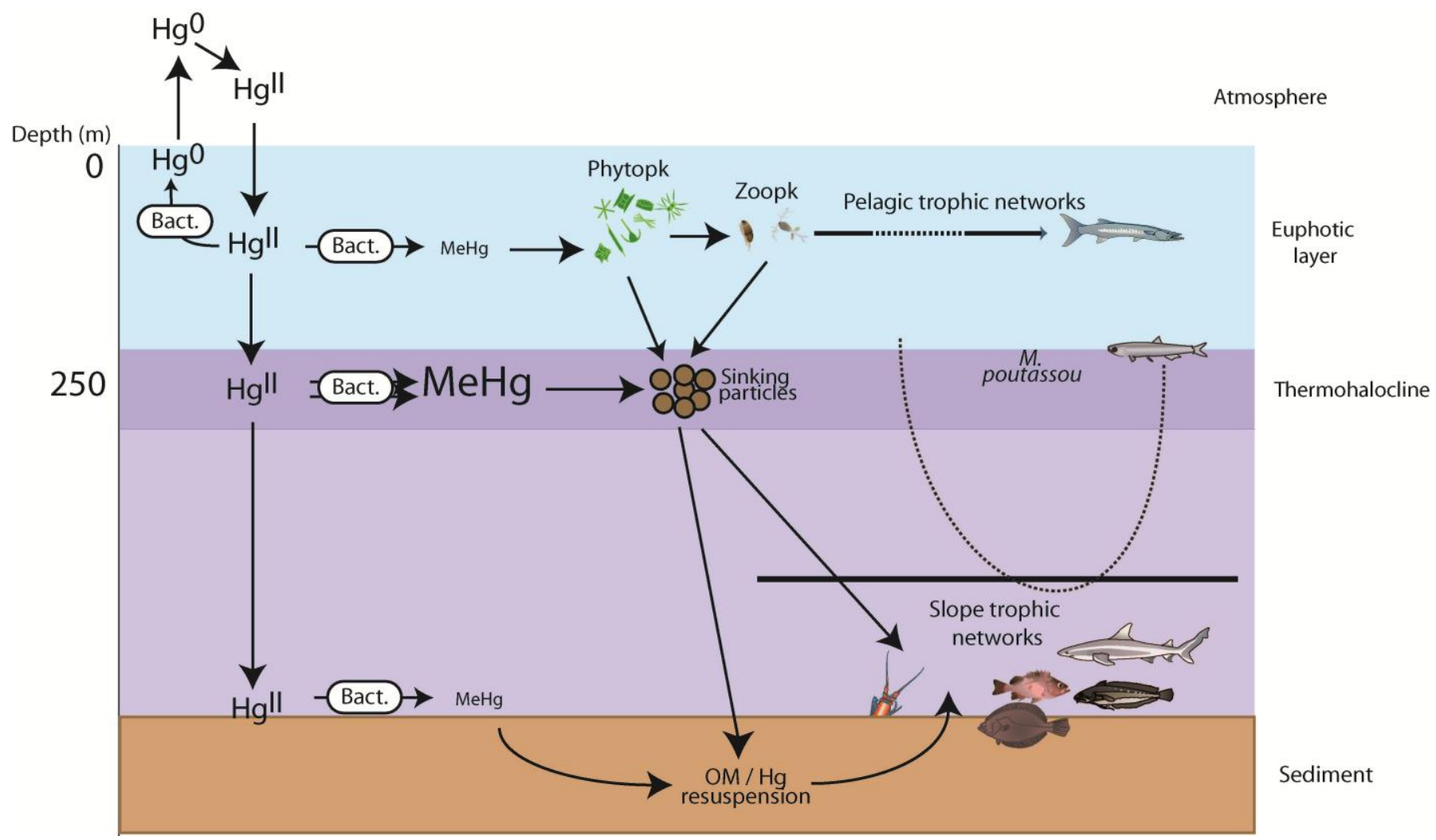




\section{Supplementary material}

Table S1: Number of individuals, total length (mean, standard deviation, minimum and maximum values), stable isotope ratios (mean and standard deviation), mean $\mathrm{C} / \mathrm{N}$ ratio (mean and standard deviation), and $\mathrm{Hg}$ concentration (mean, standard deviation and maximum value). For Nephrops norvegicus, length refers to cephalothorax length. For each species, the "mean" line presents the averaged data for this species when sampled in several points.

\begin{tabular}{|c|c|c|c|c|c|c|c|c|c|c|c|c|c|c|c|c|}
\hline & \multirow{2}{*}{ Point } & \multirow{2}{*}{$\begin{array}{l}\text { Depth } \\
(\mathrm{m})\end{array}$} & \multirow{2}{*}{$\mathrm{n}$} & \multicolumn{4}{|c|}{ Total length (mm) } & \multicolumn{2}{|c|}{$\delta^{13} \mathrm{C}(\%)$} & \multicolumn{2}{|c|}{$\delta^{15} \mathrm{~N}(\%)$} & \multicolumn{2}{|c|}{$\mathrm{C} / \mathrm{N}$} & \multicolumn{3}{|c|}{$\mathrm{Hg}\left(\mu \mathrm{g} \mathrm{g}^{-1} \mathrm{dm}\right)$} \\
\hline & & & & Mean & sd & Min & Max & Mean & sd & Mean & sd & Mean & sd & Mean & $\mathrm{sd}$ & Max \\
\hline \multirow{4}{*}{$\begin{array}{l}\text { Helicolenus dactylopterus } \\
\text { Delaroche, } 1809\end{array}$} & 404 & 369 & 6 & 206 & 29 & 179 & 246 & -18.37 & 0.80 & 9.06 & 0.79 & 3.2 & 0.1 & 5.79 & 2.27 & 9.55 \\
\hline & 05 & 426 & 10 & & 55 & 133 & 286 & -18.97 & 0.61 & 8.86 & .53 & 3.2 & 0.1 & 4.04 & 2.40 & 9.60 \\
\hline & 06 & 284 & 6 & 238 & 76 & 139 & 309 & -18.84 & 0.44 & 8.41 & 0.40 & 3.1 & 0.1 & 4.94 & 3.06 & 8.76 \\
\hline & & 679 & 6 & 227 & 40 & 164 & 274 & -17.81 & 0.30 & 9.74 & 0.36 & 3.2 & 0.0 & 9.61 & 2.69 & 12.92 \\
\hline \multirow[t]{2}{*}{ Lepidorhombus boscii Risso, 1810} & G405 & 426 & 6 & 206 & 74 & 117 & 300 & -18.70 & 0.55 & 7.91 & 0.66 & 3.2 & 0.1 & 2.25 & 1.89 & 5.37 \\
\hline & & 284 & 5 & 206 & 83 & 123 & 326 & -18.75 & 0.48 & 7.88 & 0.40 & 3.1 & 0.1 & 3.64 & 3.37 & 9.30 \\
\hline \multirow{2}{*}{$\begin{array}{c}\text { Micromesistius poutassou (Risso, } \\
1827 \text { ) }\end{array}$} & S405 & 426 & 10 & 244 & 53 & 122 & 311 & -18.91 & 0.35 & 8.64 & 0.28 & 3.2 & 0.0 & 1.41 & 0.61 & 2.41 \\
\hline & & 284 & 6 & 203 & 70 & 104 & 274 & -19.43 & 0.78 & 8.40 & 0.50 & 3.1 & 0.2 & 1.13 & 0.62 & 1.79 \\
\hline \multirow{5}{*}{$\begin{array}{c}\text { Phycis blennoides (Brünnich, } \\
\text { 1768) }\end{array}$} & 405 & 426 & 13 & 186 & 57 & 112 & 279 & -19.30 & 0.49 & 8.85 & 0.57 & 3.1 & 0.0 & 1.38 & 0.89 & 3.02 \\
\hline & G406 & 284 & 5 & 208 & 62 & 114 & 273 & -19.57 & 0.46 & 8.88 & 0.48 & 3.1 & 0.1 & 1.00 & 0.38 & 1.37 \\
\hline & G502 & 665 & 6 & 264 & 54 & 203 & 341 & -18.61 & 0.18 & 9.31 & 0.61 & 3.1 & 0.1 & 2.36 & 0.49 & 2.84 \\
\hline & G503 & 679 & 6 & 272 & 67 & 193 & 377 & -18.42 & 0.33 & 9.16 & 1.11 & 3.1 & 0.3 & 3.08 & 1.28 & 4.21 \\
\hline & G504 & 816 & 2 & 221 & 2 & 219 & 222 & -19.02 & 0.11 & 9.73 & 0.35 & 3.2 & 0.0 & 2.57 & 0.15 & 2.68 \\
\hline \multirow{5}{*}{$\begin{array}{l}\text { Galeus melastomus Rafinesque, } \\
1810\end{array}$} & & 50 & 7 & 348 & 48 & & 403 & -18.29 & 0.28 & 7.95 & 0. & 2.5 & 0.1 & & 0.99 & 4.83 \\
\hline & G405 & 426 & 12 & 321 & 149 & 132 & 526 & -18.41 & 0.37 & 8.30 & 0.78 & 2.8 & 0.3 & 5.03 & 3.50 & 12.06 \\
\hline & G406 & 284 & 6 & 333 & 135 & 182 & 505 & -18.50 & 0.73 & 8.42 & 1.03 & 2.8 & 0.1 & 5.64 & 5.73 & 16.72 \\
\hline & G503 & 679 & 5 & 409 & 74 & 321 & 484 & -18.05 & 0.39 & 8.82 & 0.64 & 2.7 & 0.1 & 5.32 & 3.86 & 11.86 \\
\hline & G504 & 816 & 6 & 370 & 185 & 136 & 558 & -18.25 & 0.59 & 8.49 & 0.79 & 2.6 & 0.1 & 5.75 & 3.82 & 11.58 \\
\hline \multirow{3}{*}{$\begin{array}{c}\text { Scyliorhinus canicula (Linnaeus, } \\
1758 \text { ) }\end{array}$} & G404 & 369 & 5 & 447 & 76 & 333 & 507 & -18.27 & 0.29 & 8.75 & 0.45 & 2.6 & 0.0 & 10.50 & 6.59 & 18.08 \\
\hline & G406 & 284 & 6 & 280 & 116 & 164 & 439 & -18.69 & 0.51 & 8.04 & 0.57 & 2.7 & 0.1 & 2.60 & 1.47 & 4.51 \\
\hline & G502 & 665 & 6 & 431 & 119 & 279 & 569 & -17.99 & 0.19 & 8.59 & 0.54 & 2.6 & 0.0 & 8.86 & 9.19 & 27.01 \\
\hline $\begin{array}{c}\text { Nephrops norvegicus (Linnaeus, } \\
1758 \text { ) }\end{array}$ & G405 & 426 & 13 & 31 & 11 & 16 & 50 & -19.08 & 0.64 & 6.62 & 0.54 & 3.3 & 0.2 & 1.80 & 0.97 & 4.14 \\
\hline
\end{tabular}


Tab. S2: Interspecific variations of isotopic ratios, compared with ANOVA. Post-hoc: results of the post-hoc comparison tests (Gm: Galeus melastomus, Hd: Helicolenus dactylopterus, Lb: Lepidorhombus boscii, Mp: Micromesistius poutassou, Nn: Nephrops norvegicus, Pb: Phycis blennoides, Sc: Scyliorhinus canicula)

\begin{tabular}{|l|l|l|l|}
\hline Parameter & Statistics & p-value & Post hoc \\
\hline$\delta^{13} \mathrm{C}$ & $\mathrm{F}_{6,146)}=8.17$ & $<0.001$ & $\mathrm{Mp}=\mathrm{Nn}=\mathrm{Pb}<\mathrm{Lb}=\mathrm{Hd}<\mathrm{Gm}=\mathrm{Sc}$ \\
\hline$\delta^{15} \mathrm{~N}$ & $\mathrm{~F}_{(6,146)}=29.90$ & $<0.001$ & $\mathrm{Nn}<\mathrm{Lb}<\mathrm{Gm}=\mathrm{Sc}=\mathrm{Mp}<\mathrm{Hd}=\mathrm{Pb}$ \\
\hline
\end{tabular}


Tab. S3: Parameters of the regressions between total length $(\mathrm{TL}), \delta^{15} \mathrm{~N}$ and $\mathrm{Hg}$ concentrations $(\mathrm{Hg})$, using linear or exponential regressions models. The chosen model was the one with a significant correlation ("sig" column; ${ }^{* * *}: p$-value $\leq 0.001 ;{ }^{* *}: p$-value $\leq$ 0.01, ,: $p$-value $\leq 0.05$; ns: non-significant, p-value>0.005) and with the minimal AIC (Aikake Information Criterion) .Model chosen is highlighted in grey

\begin{tabular}{|c|c|c|c|c|c|c|c|c|c|c|c|c|c|c|c|c|c|c|}
\hline & \multicolumn{3}{|c|}{$\delta^{15} \mathrm{~N}=\mathrm{a} \mathrm{TL}+\mathrm{b}$} & \multicolumn{3}{|l|}{$\delta^{15} \mathrm{~N}=\mathrm{a} \mathrm{e}^{\mathrm{bTL}}$} & \multicolumn{3}{|l|}{$\mathrm{Hg}=\mathrm{a} T \mathrm{~T}+\mathrm{b}$} & \multicolumn{3}{|l|}{$\mathrm{Hg}=\mathrm{a} \mathrm{e}^{\mathrm{bTL}}$} & \multicolumn{3}{|c|}{$\mathrm{Hg}=\mathrm{a} \delta^{15} \mathrm{~N}+\mathrm{b}$} & \multicolumn{3}{|c|}{$\mathrm{Hg}=a \mathrm{e}^{\mathrm{b} \delta 15 \mathrm{~N}}$} \\
\hline & Coeff. & AIC & Sig. & Coeff. & AIC & Sig. & Coeff. & AIC & Sig. & Coeff. & AIC & Sig. & Coeff. & AIC & Sig. & Coeff. & AIC & Sig. \\
\hline$G m$ & $\begin{array}{l}\mathrm{a}=4.7610^{-3} \\
\mathrm{~b}=6.63\end{array}$ & 36.95 & $* * *$ & $\begin{array}{l}\mathrm{a}=5.9110^{-4} \\
\mathrm{~b}=1.91\end{array}$ & 35.12 & $* * *$ & $\begin{array}{l}a=0.02 \\
b=-2.20\end{array}$ & 170.92 & $* * *$ & $\begin{array}{l}a=5.9210^{-3} \\
b=-0.75\end{array}$ & 155.48 & $* * *$ & $\begin{array}{l}a=4.28 \\
b=-30.62\end{array}$ & 153.3 & $* * *$ & $\begin{array}{l}a=0.70 \\
b=-4.34\end{array}$ & 149.89 & $* * *$ \\
\hline$H d$ & $\begin{array}{l}\mathrm{a}=3.8910^{-3} \\
\mathrm{~b}=8.17\end{array}$ & 60.52 & ns & $\begin{array}{l}\mathrm{a}=4.2110^{-4} \\
\mathrm{~b}=2.11\end{array}$ & 60.59 & ns & $\begin{array}{l}a=0.04 \\
b=-2.54\end{array}$ & 134.54 & $* * *$ & $\begin{array}{l}\mathrm{a}=5.6410^{-3} \\
\mathrm{~b}=0.53\end{array}$ & 137.29 & $* *$ & $\begin{array}{l}\mathrm{a}=2.84 \\
\mathrm{~b}=-19.79\end{array}$ & 137.6 & $* * *$ & $\begin{array}{l}a=0.58 \\
b=-3.56\end{array}$ & 133.7 & $* * *$ \\
\hline$L b$ & $\begin{array}{l}\mathrm{a}=4.4110^{-3} \\
\mathrm{~b}=6.95\end{array}$ & 14.39 & $*$ & $\begin{array}{l}\mathrm{a}=5.4610^{-4} \\
\mathrm{~b}=1.95\end{array}$ & 14.57 & $*$ & $\begin{array}{l}\mathrm{a}=0.03 \\
\mathrm{~b}=-2.94\end{array}$ & 43.80 & $*$ & $\begin{array}{l}\mathrm{a}=0.01 \\
\mathrm{~b}=-2.00\end{array}$ & 34.77 & $* * *$ & $\begin{array}{l}a=1.45 \\
b=-8.75\end{array}$ & 51.76 & ns & $\begin{array}{l}a=0.47 \\
b=-2.74\end{array}$ & 51.93 & ns \\
\hline$M p$ & $\begin{array}{l}\mathrm{a}=3.2710^{-3} \\
\mathrm{~b}=7.80\end{array}$ & 14.27 & $*$ & $\begin{array}{l}\mathrm{a}=3.9210^{-4} \\
\mathrm{~b}=2.06\end{array}$ & 14.12 & $*$ & $\begin{array}{l}a=9.2410^{-3} \\
b=-0.81\end{array}$ & 2.72 & $* * *$ & $\begin{array}{l}\mathrm{a}=8.6710^{-3} \\
\mathrm{~b}=-1.82\end{array}$ & -1.31 & $* * *$ & $\begin{array}{l}a=0.95 \\
b=-6.84\end{array}$ & 27.44 & $*$ & $\begin{array}{l}a=0.65 \\
b=-5.34\end{array}$ & 27.70 & $*$ \\
\hline $\mathrm{Nn}$ & $\begin{array}{l}a=0.03 \\
b=5.72\end{array}$ & 20.35 & * & $\begin{array}{l}\mathrm{a}=4.3110^{-3} \\
\mathrm{~b}=1.75\end{array}$ & 20.38 & $*$ & $\begin{array}{l}\mathrm{a}=0.05 \\
\mathrm{~b}=0.14\end{array}$ & 34.80 & $*$ & $\begin{array}{l}\mathrm{a}=0.02 \\
\mathrm{~b}=-0.20\end{array}$ & 35.73 & ns & $\begin{array}{l}a=0.66 \\
b=-2.60\end{array}$ & 39.10 & ns & $\begin{array}{l}a=0.35 \\
b=-1.75\end{array}$ & 39.10 & ns \\
\hline $\mathrm{Pb}$ & $\begin{array}{l}\mathrm{a}=8.3110^{-3} \\
\mathrm{~b}=7.32\end{array}$ & 25.42 & *** & $\begin{array}{l}\mathrm{a}=9.0010^{-4} \\
\mathrm{~b}=2.01\end{array}$ & 26.47 & $* * *$ & $\begin{array}{l}a=0.01 \\
b=-1.20\end{array}$ & 61.04 & $* * *$ & $\begin{array}{l}\mathrm{a}=6.5910^{-3} \\
\mathrm{~b}=-0.90\end{array}$ & 66.96 & $* * *$ & $\begin{array}{l}a=1.48 \\
b=-11.69\end{array}$ & 51.40 & $* * *$ & $\begin{array}{l}a=0.85 \\
b=-7.27\end{array}$ & 50.19 & $* * *$ \\
\hline$S c$ & $\begin{array}{l}\mathrm{a}=4.2910^{-3} \\
\mathrm{~b}=6.80\end{array}$ & -1.60 & $* * *$ & $\begin{array}{l}a=5.1110^{-4} \\
b=1.94\end{array}$ & -1.20 & $* * *$ & $\begin{array}{l}a=0.04 \\
b=-8.74\end{array}$ & 106.03 & $* * *$ & $\begin{array}{l}a=0.01 \\
b=-2.72\end{array}$ & 94.14 & $* * *$ & $\begin{array}{l}a=8.07 \\
b=-60.45\end{array}$ & 110.06 & $* *$ & $\begin{array}{l}a=1.45 \\
b=-10.63\end{array}$ & 108.39 & * \\
\hline
\end{tabular}


Table S4: Parameters of the regression between total length and $\delta^{13} \mathrm{C}\left({ }^{* * *}: \mathrm{p}\right.$-value $\leq 0.001 ;{ }^{* *}: \mathrm{p}$-value $\leq 0.01{ }^{*}: \mathrm{p}$-value $\leq 0.05$; ns: non-significant, $p$-value $>0.05$ )

\begin{tabular}{|l|l|l|l|}
\hline & \multicolumn{3}{|l|}{$\delta^{13} \mathrm{C}=\mathrm{a} \mathrm{LT}+\mathrm{b}$} \\
\hline & coeff & $\mathrm{r}^{2}$ & sig \\
\hline G. melastomus & $\mathrm{a}=2.910^{-3}$ & 0.63 & $* * *$ \\
& $\mathrm{~b}=-19.36$ & & \\
\hline H. dactylopterus & $\mathrm{a}=0.0007$ & 0.30 & $* *$ \\
& $\mathrm{~b}=-20.09$ & & \\
\hline L. boscii & $\mathrm{a}=0.005$ & 0.40 & $*$ \\
& $\mathrm{~b}=-19.73$ & & \\
\hline M. poutassou & $\mathrm{a}=0.005$ & 0.35 & $*$ \\
& $\mathrm{~b}=-20.39$ & & \\
\hline N. norvegicus & $\mathrm{a}=0.02$ & 0.08 & $\mathrm{~ns}$ \\
& $\mathrm{~b}=-19.60$ & & \\
\hline P. blennoides & $\mathrm{a}=0.007$ & 0.56 & $* * *$ \\
& $\mathrm{~b}=-20.58$ & & \\
\hline S. canicula & $\mathrm{a}=0.003$ & 0.57 & $*$ \\
& $\mathrm{~b}=-19.36$ & & \\
\hline
\end{tabular}

